AWARD NUMBER: W81XWH 12 12100533

TITLE: Role of TAF12 in the Increased VDR Activity in Paget's Disease of Bone

PRINCIPAL INVESTIGATOR: Kurihara, Noriyoshi

प

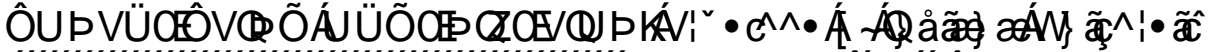

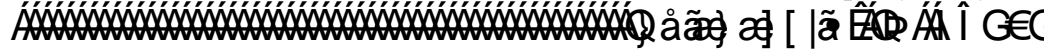

REPORT DATE: 2 \&7पिए।

TYPE OF REPORT: Annual

PREPARED FOR: U.S. Army Medical Research and Materiel Command Fort Detrick, Maryland 21702-5012

DISTRIBUTION STATEMENT: Approved for Public Release;

Distribution Unlimited

The views, opinions and/or findings contained in this report are those of the author(s) and should not be construed as an official Department of the Army position, policy or decision unless so designated by other documentation. 


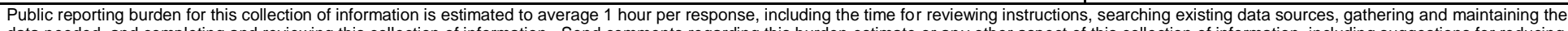

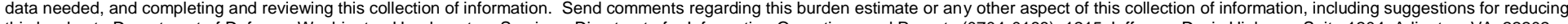

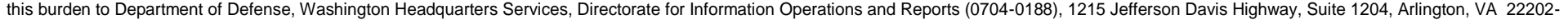

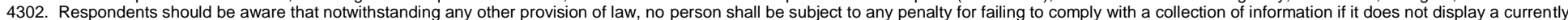
valid OMB control number. PLEASE DO NOT RETURN YOUR FORM TO THE ABOVE ADDRESS.

\section{\begin{tabular}{l|l} 
1. REPORT DATE & 2. REPORT TYPE
\end{tabular}}

October 2014 Annual

\section{TITLE AND SUBTITLE}

Role of TAF12 in the Increased VDR Activity in Paget's Disease of Bone

6. AUTHOR(S)

Kurihara, Noriyoshi
3. DATES COVERED

30 Sep 2013 - 29 Sep 2014

5a. CONTRACT NUMBER

5b. GRANT NUMBER

W81XWH -12 -1-0533

5c. PROGRAM ELEMENT NUMBER

5d. PROJECT NUMBER

5e. TASK NUMBER

5f. WORK UNIT NUMBER

Email: norikuri@iupui.edu

7. PERFORMING ORGANIZATION NAME(S) AND ADDRESS(ES)

Trustees of Indiana University

Indianapolis, IN 46202

9. SPONSORING / MONITORING AGENCY NAME(S) AND ADDRESS(ES)

U.S. Army Medical Research and Materiel Command

Fort Detrick, Maryland 21702-5012

12. DISTRIBUTION / AVAILABILITY STATEMENT

Approved for Public Release; Distribution Unlimited
10. SPONSOR/MONITOR'S ACRONYM(S)

8. PERFORMING ORGANIZATION REPORT NUMBER

11. SPONSOR/MONITOR'S REPORT NUMBER(S)

13. SUPPLEMENTARY NOTES

\section{ABSTRACT}

attached

15. SUBJECT TERMS-

Nothing listed

\section{SECURITY CLASSIFICATION OF:}

a. REPORT

U

\section{b. ABSTRACT}

U
17. LIMITATION OF ABSTRACT

c. THIS PAGE

U
18. NUMBER OF PAGES

UU 19a. NAME OF RESPONSIBLE PERSON USAMRMC

19b. TELEPHONE NUMBER (include area code) 
[SF298]

\section{Note: An abstract is required to be provided in Block 14}

Osteoclast (OCL) precursors from many Paget's disease (PD) patients express measles virus nucleocapsid protein (MVNP) and are hypersensitive to 1,25dihydroxyvitamin $D_{3}\left(1,25-(O H)_{2} D_{3}\right.$; also known as calcitriol). The increased 1,25$(\mathrm{OH})_{2} \mathrm{D}_{3}$ sensitivity is mediated by transcription initiation factor TFIID subunit 12 (TAF12), a coactivator of vitamin D receptor (VDR) mediated transcriptionTAF12 is present at much higher levels in MVNP-expressing OCL precursors than normals. These results suggest that TAF12 plays an important role in the abnormal OCL activity in PD. However, the molecular mechanisms underlying both $1,25-(\mathrm{OH})_{2} \mathrm{D}_{3}$ 's effects on OCL formation and the contribution of TAF12 to these effects in both normals and PD patients are unclear. Inhibition of TAF12 with a specific TAF12 anti-sense construct decreased OCL formation and the sensitivity of $\mathrm{OCL}$ precursors to $1,25-(\mathrm{OH})_{2} \mathrm{D}_{3}$ in $\mathrm{PD}$ patient bone marrow samples. Further, OCL precursors from transgenic mice in which TAF12 expression was targeted to the OCL lineage (tartrate-resistant acid phosphatase TRAP-TAF12 mice), formed OCLs at very low levels of $1,25-(\mathrm{OH})_{2} \mathrm{D}_{3}$, although the OCLs failed to exhibit other hallmarks of PD OCLs, including hypermultinucleation and receptor activator of NF-KB ligand (RANKL) hypersensitivity. Chromatin immunoprecipitation (ChIP) analysis of OCL precursors using an antiTAF12 antibody demonstrated that TAF12 binds the 24-hydroxylase (CYP24A1) promoter, which contains two functional vitamin $D$ response elements (VDREs), in the presence of $1,25-(\mathrm{OH})_{2} \mathrm{D}_{3}$. Because TAF12 directly interacts with the cyclic adenosine monophosphate-dependent activating transcription factor 7 (ATF7) and potentiates ATF7-induced transcriptional activation of ATF7-driven genes in other cell types, we determined whether TAF12 is a functional partner of ATF7 in $\mathrm{OCL}$ precursors. Immunoprecipitation of lysates from either wild-type (WT) or MVNP-expressing OCL with an anti-TAF12 antibody, followed by blotting with an anti-ATF7 antibody, or vice versa, showed that TAF12 and ATF7 physically interact in OCLs. Knockdown of ATF7 in MVNP-expressing cells decreased 
CYP24A1induction by $1,25-(\mathrm{OH})_{2} \mathrm{D}_{3}$, as well as TAF12 binding to the CYP24A1 promoter. Our most recent results show that TAF4 is also involved in TAF12 effects in PD. These results show that ATF7 interacts with TAF12 and contributes with TAF4 to the $1,25-(\mathrm{OH})_{2} \mathrm{D}_{3}$ hypersensitivity of OCL precursors in PD. 


\section{Table of Contents}

Page

1. Introduction

2. Keywords

3. Accomplishment 5

$\begin{array}{ll}\text { 4. Impact } & 9\end{array}$

5. Changes/problems 9

$\begin{array}{ll}\text { 6. Products } & 9\end{array}$

7. Participants \& other collaborating organizations 9

8. Special reporting Requirements 9

$\begin{array}{ll}\text { 9. Appendices DWTFHG } & \text { DWT }\end{array}$ 


\section{INTRODUCTION:}

Vitamin $D$ is a key regulator of bone homeostasis, but its effects on osteoclasts (OCLs) beyond the capacity of $1,25-(\mathrm{OH})_{2} \mathrm{D}_{3}$ to induce RANKL and decrease OPG in stromal cells are unclear. We previously reported that OCL precursors from PD patients are hypersensitive to $1,25-(\mathrm{OH})_{2} \mathrm{D}_{3}$ and form OCLs at physiologic rather than pharmacologic levels of vitamin $D$. We found that the increased 1,25$(\mathrm{OH})_{2} \mathrm{D}_{3}$ sensitivity is mediated by TAF12, a novel coactivator of VDR, and plays an important role in the abnormal OCL activity in Paget's Disease (PD). Further, increased expression of TAF12 in NIH3T3 cells or marrow stromal cells also increases their sensitivity to $1,25-(\mathrm{OH})_{2} \mathrm{D}_{3}$, indicating that TAF12 can act as a VDR coactivator in multiple cell types. However, the molecular mechanisms underlying both vitamin $D_{3}$ 's effects on OCL formation and the contribution of TAF12 to these effects in both normals and PD patients are undefined. Since PD represents one of the most exaggerated examples of coupled bone remodeling, studies of PD provide a paradigm for understanding the molecular mechanisms regulating both normal and pagetic $\mathrm{OCL}$ and osteoblast activity. Therefore, we will examine the mechanisms of action of TAF12 on VDR-mediated transcription in OCL precursors (OCL-P), CD11b purified marrow cells, and the effects of deletion of TAF12 on bone remodeling and the development of PD in Measles Virus Nucleocapsid Protein (MVNP) expressing OCL-P in vivo as a PD model system that develops PD-like OCLs and bone lesions.

\section{KEYWORD:}

TAF12, Paget's bone disease, Measles virus nucleocapsid protein (MVNP), ATF7, TAF4, Osteoclast (OCL), VDR, CYP24A1

\section{ACCOMPLISHMENT:}

Aim1. Determine the mechanism(S) whereby TAF12 enhances cellular responsiveness to $1,25-(\mathrm{OH})_{2} \mathrm{D}_{3}$ /VDR-mediated transcription in osteoclast $(\mathrm{OCL})$ precursors.

Task 1B. Determine the role of TAF12.ATF7/TAF4 interactions in $1,25-(\mathrm{OH})_{2} \mathrm{D}_{3}$ hypersensitivity. 
1B2. Determine if the effects of TAF12 on VDR-mediated transcription of CYP24A1 is ATF7 and/or TAF4-dependent.

\section{Purpose of study:}

Aim of study of Task 1 Aim1B (0-12 months) is to examine either TAF12.ATF7 and /or TAF12-TAF4 are important for increasing the sensitivity of VDRdriven genes to physiological levels of $1,25-(\mathrm{OH})_{2} \mathrm{D}_{3}$. TAF4, which forms a heterodimer with TAF12 via mutual histone fold domains (HFD) can heterodimerize with ATF7. Our goal will be to establish if TAF4 is a negative or positive cofactor in the TAF12.ATF7mediated increased VDR activity which was reported in Task1 Aim1A. For this study, we used a shRNA to TAF4 to determine if TAF4 is required for CYP24A1 gene hypersensitivity to $1,25-(\mathrm{OH})_{2} \mathrm{D}_{3}$ induced by TAF12.

\section{Methods:}

TAF4 shRNA transduction: Non-adherent bone marrow cells from TRAPMVNP and WT mice were transduced with TAF4 shRNA (NM_1081092) (Sigma-Aldrich) or control shRNA (Sigma-Aldrich) which were designed by MISSION ${ }^{\circledR}$. shRNA Lentiviral transduction particles (Sigma-Aldrich) were used for transduction. The transduction was performed by the MagnetoFection ${ }^{\mathrm{TM}}$-ViroMag R/L method ( $\mathrm{OZ}$ Biosciences). To increase the transduction efficiency, the cells were plated the day before transduction in $35 \mathrm{~mm}$ culture dish in the presence of $10 \mathrm{ng} / \mathrm{ml}$ of M-CSF and $2 \mu \mathrm{l}$ of ViroMag R/L beads in $50 \mathrm{pl}$ of aMEM 10\%FCS, $500 \mathrm{MOI}$ of Lentiviral transduction particles were added, and the cells incubated for $15 \mathrm{~min}$ at room temperature. Then $50 \mu \mathrm{l}$ of virus particles/magnet were mixed in each well and cells were incubated on a magnet plate for $60 \mathrm{~min}$. The culture plates were removed from the magnetic plate and cells were cultured with RANKL $(50 \mathrm{ng} / \mathrm{ml})$ for 3 days and $1,25-(\mathrm{OH})_{2} \mathrm{D}_{3}\left(10^{-10} \mathrm{M}\right)$ for $2-3$ days (Figure 1). 


\section{Results:}

TAF4 expression levels were decreased by $66.7 \%$ in OCL precursors from MVNP mice injected with shRNA for TAF4 as compared to control shRNA transduced cells (Figure 2). Osteoclast formation induced by $1,25-\mathrm{OH})_{2} \mathrm{D}_{3}$ in TAF4 k/d osteoclast precursors was deceased by $80 \%$ in culture from WT mice and $70 \%$ in cultures from MVNP mice compared to control shRNA transduced cultures (Figure 3). OCLs from TAF4 shRNA transduced OCL precursors from both WT and MVNP mice were smaller in size and had decreased nuclei/OCL than control shRNA transduced OCLs (Data not shown). We then examined CYP24A1 expression in TAF4 k/d OCL. As expected, CYP24A1 expression was decreased by $50 \%$ compared to control shRNA in WT transduced cells as shown Figure 4, and the marked increase in CYP24A1 induced by $1,25-(\mathrm{OH})_{2} \mathrm{D}_{3}$ was totally blocked in MVNP cells. These results indicate that TAF4 is required for maximal levels of $\mathrm{OCL}$ formation in response to $1,25-(\mathrm{OH})_{2} \mathrm{D}_{3}$ and enhancement of VDR activity in MVNP expressing OCL at physiological concentration of $1,25-(\mathrm{OH})_{2} \mathrm{D}_{3}\left(10^{-10} \mathrm{M}\right)$.

\section{Conclusion:}

TAF4 is important for OCL formation induced by physiologic levels of 1,25$(\mathrm{OH})_{2} \mathrm{D}_{3}$, and the enhanced VDR responsively in MVNP expressing OCL.

\section{Aim 2. Determine the coactivator mechanism of TAF12 and its effects on VDR target genes.}

Task 2. Define the coactivator mechanisms of action of TAF12 at the CYP24A1 gene locus. Use chromatin immunoprecipitation and ChIP-chip analysis to explore the potential impact of TAF12 on VDR/RXR binding at the CYP24A1 locus and the requirement of components of the general transcriptional apparatus (TBP, TFIIB, and DRIP205) and VDR interacting with the histone acetyltransferases (SRC1, CBBP etc) that control entry and activity of RNA polymerase II for TAF12's effects. (Months 12-24). 
Mice with conditional deletion of TAF12 have been generated at the end of the first year. Therefore, we screened OCL precursors from these mice for TAF12 expression and OCL formation. We focused initially on Aim3 (TASK3A and B), and we postponed Aim 2 (Months 12-24) to months 24-36. We are confident that we will complete Task 2 by month 36, because we are very experienced with using Chip-analyses to examine CYP24A1 promoter activity as a candidate VDR target gene.

\section{Aim 3. Determine the role of TAF12 in normal and pagetic OCL activity in vivo.}

Task 3A.Development of TAF12-/-, TRAP-MVNP/TAF12-/- mice and mice with a conditional deletion of TAF12 (months 1-36).

Task 3B. Evaluation of TRAP-MVNP/TAF12 ${ }^{-/-}$mice in vitro and in vivo as compared to TRAP-MVNP or WT controls.

Purpose of study: We have characterized the bone phenotype of TRAP-TAF12 mice at a range of ages to determine the effects of persistent elevation of TAF12 on OCL formation and bone remodeling in vivo (Teramachi et al, JBMR 2013). We examined if OCL precursors from these mice have enhanced vitamin $D$ responsivity. This study will allow us to compare these results with studies of the effects of TAF12 deficiency on bone in vivo.

We generated germ-line and conditional TAF12 knockout mice to confirm that TAF12 increased OCL formation on MVNP expressing OCL-precursors in response to $1,25-(\mathrm{OH})_{2} \mathrm{D}_{3}$. In preliminary experiments, we made TAF12 global and conditional knock out mice as indicated in our grant application by deletion of exons 3-5 of TAF12. However $\mathrm{TAF}_{12}{ }^{-/}$mice die during gestation. We have changed the original experimental plan to generate TAF12 heterozygous knockout $\left(\mathrm{TAF}_{12}{ }^{+/}\right)$and heterozygous knockout floxed mice $\left(\mathrm{TAF} 12^{\text {flox/- }}\right)$. Since we have previously developed TRAP-Cre mice, we generated conditional TRAP-Cre/TAF12 $2^{\text {flox/- }}$ mice in collaboration with Dr. Jolene Windle (Virginia Commonwealth University). 


\section{Results;}

As reported in the first year's progress report, TAF12 ${ }^{-1-}$ mice displayed an embryonic lethal phenotype. Therefore, we focused on the TRAP-Cre/TAF12 ${ }^{\text {floxl- }}$ or $\mathrm{TAF}_{12}{ }^{+-}$conditional knockout mice to examine the role of TAF12 in OCL-precursors.

We generated a variety TRAP-Cre/TAF12 heterozygous knockout mice as shown in Figure 5B and C. We determined the protein levels of TAF12 as shown Figure 5C. Because whole bone marrow cultures contain osteoclasts, macrophages, mesenchymal stem cell derived cells and stromal cells; we used trypsin digestion to remove non-osteoclastic cells and increase the concentration of osteoclasts in the cultures. (Figure 5A) Osteoclasts are not released by trypsin. As shown Figure 5C, OCL from the TRAP-Cre $(+) / T A F 12^{\text {flox/- }}$ mice had at least a $50 \%$ decrease of TAF12 expression compared to TRAP-Cre(-)/TAF12 $2^{\text {flox/- }}$ and WT. Surprisingly TRAP-Cre(/TAF12 $2^{\text {flox/- }}$ and WT OCL expressed similarly levels of TAF12 (Figure $5 \mathrm{C}$ ).

The expression of ATF7 and TAF4 which can heterodimerize with TAF12 was then determined in OCL from TRAP-Cre(+)/TAF12 $2^{\text {flox/- }}$, TRAP-Cre(-)/TAF12 $2^{\text {flox/- }}$ and WT mice by Western blotting. Expression levels of ATF7 were not changed, but TAF4 expression in OCL from TRAP-Cre(+)/TAF12 flox/- was significantly decreased by $90 \%$ compared to OCL derived from the other phenotypes (Figure 6). The decrease in TAF4 may have occurred because TAF12 knockdown can decrease TAF12-TAF4 histone-fold heterodimer formation in hepatocyte cells (Alpen et al, eLife 2014:3e03613).

OCL-precursors from TRAP-Cre(+)/TAF12 $2^{\text {floxl- }}$ were not hyper-responsive to $1,25-(\mathrm{OH})_{2} \mathrm{D}_{3}$ and formed lower numbers of OCL compared TRAP-Cre(-)/TAF12 $2^{\text {floxl- }}$ and WT mice (Figure 7B). The levels of OCL formation in cultures treated with RANKL were similar for all genotypes (Figure 7C).

\section{Conclusion:}

TAF12 acts as a VDR coactivator and plays an important role in osteoclast formation stimulated by $1,25-(\mathrm{OH})_{2} \mathrm{D}_{3}$. The TRAP-Cre $(+) / \mathrm{TAF} 12^{\text {flox/- }}$ mice will provide an appropriate model for in vivo experiments in which knockdown of TAF12 is directed to cells in OCL lineage as well as in determining the roles of ATF7, TAF12, and TAF4 in VDR-mediated gene expression in OCL-precursors. 


\section{IMPACT:}

- TAF4 is important for TAF12's effects on OCL formation by $1,25-(\mathrm{OH})_{2} \mathrm{D}_{3}$.

- Knockdown of TAF4 in MVNP-expressing cells decreased CYP24A1 induction by $1,25-(\mathrm{OH})_{2} \mathrm{D}_{3}$.

- Knockdown TAF12 (TRAP-Cre $(+) / T A F 12^{\text {flox/- })}$ mice have been developed for studies in TASK 3.

- OCL-precursors from TRAP-Cre(+)/TAF12 ${ }^{\text {flox/- }}$ were not hyper-responsive to $1,25-$ $(\mathrm{OH})_{2} \mathrm{D}_{3}$ compared TRAP-Cre(-)/TAF12 $2^{\text {floxl- }}$ and WT and formed lower OCL. The OCL formation by these OCL-precursors treated with RANKL did not differ.

\section{CHANGES/PROBLEMS:}

Mice with conditional deletion of TAF12 have been generated at the end of first year; we have screened them for TAF12 expression and OCL formation in vitro. We have focused initially on Aim3 (TASK3A and B), and postponed Aim 2 (Months 12-24) to months 24-36. We will perform Task 2 by the end of month 36, because we are familiar with Chip-analyses to examine the CYp24A1 promoter as a candidate for VDR targeted genes.

\section{PRODUCTS:}

Models: To determine the role of TAF12 in normal and pagetic OCL activity in vivo, we developed TAF12 $2^{\text {floxl- }}$ mice or TRAP-Cre $(+) / T A F 12^{\text {floxl- }}$ mice (Task 3A)

7. PARTICIPANTS \&OTHER COLLABORATING ORGANIZATION: None

8. SPECIAL REPORTING REQUIREMENTS: None

\section{APPENDICES:}

(1) J Bone Miner Res. 2014; 29(6):1456-1465 (PDF file)

(2) Figures 1-7 


\title{
Increased IL-6 Expression in Osteoclasts Is Necessary But Not Sufficient for the Development of Paget's Disease of Bone
}

\author{
Jumpei Teramachi, ${ }^{1}$ Hua Zhou, ${ }^{2}$ Mark A Subler, ${ }^{3}$ Yukiko Kitagawa, ${ }^{1}$ Deborah L Galson, ${ }^{4}$ David W Dempster, \\ Jolene J Windle, ${ }^{3}$ Noriyoshi Kurihara, ${ }^{1}$ and G David Roodman ${ }^{1,5}$ \\ ${ }^{1}$ Department of Medicine, Hematology Oncology, Indiana University, Indianapolis, IN \\ ${ }^{2}$ Department of Pathology, College of Physician and Surgeons, Columbia University, New York, NY \\ ${ }^{3}$ Department of Human and Molecular Genetics, Virginia Commonwealth University, Richmond, VA \\ ${ }^{4}$ Department of Medicine, Hematology Oncology, University of Pittsburgh, Pittsburgh, PA \\ ${ }^{5}$ Department of Medicine, Richard L. Roudebush VA Medical Center, Indianapolis, IN
}

\begin{abstract}
Measles virus nucleocapsid protein (MVNP) expression in osteoclasts (OCLs) and mutation of the SQSTM1 (p62) gene contribute to the increased OCL activity in Paget's disease (PD). OCLs expressing MVNP display many of the features of PD OCLs. Interleukin-6 (IL-6) production is essential for the pagetic phenotype, because transgenic mice with MVNP targeted to OCLs develop pagetic OCLs and lesions, but this phenotype is absent when MVNP mice are bred to IL- $6^{-1-}$ mice. In contrast, mutant p62 expression in OCL precursors promotes receptor activator of NF-кB ligand (RANKL) hyperresponsivity and increased OCL production, but OCLs that form have normal morphology, are not hyperresponsive to 1,25-dihydroxyvitamin $D_{3}\left(1,25-(\mathrm{OH})_{2} \mathrm{D}_{3}\right)$, nor produce elevated levels of IL-6. We previously generated $p 62^{P 394 L}$ knock-in mice $(p 62 \mathrm{KI})$ and found that although OCL numbers were increased, the mice did not develop pagetic lesions. However, mice expressing both $M V N P$ and $p 62 \mathrm{KI}$ developed more exuberant pagetic lesions than mice expressing MVNP alone. To examine the role of elevated IL- 6 in PD and determine if MVNP mediates its effects primarily through elevation of IL-6, we generated transgenic mice that overexpress IL- 6 driven by the tartrate-resistant acid phosphatase (TRAP) promoter (TIL- 6 mice) and produce IL- 6 at levels comparable to MVNP mice. These were crossed with $p 62 \mathrm{KI}$ mice to determine whether IL- 6 overexpression cooperates with mutant $p 62$ to produce pagetic lesions. OCL precursors from $p 62 \mathrm{KI} / \mathrm{T} / \mathrm{L}-6$ mice formed greater numbers of OCLs than either $p 62 \mathrm{KI}$ or T/L-6 OCL precursors in response to $1,25-(\mathrm{OH})_{2} \mathrm{D}_{3}$. Histomorphometric analysis of bones from $p 62 \mathrm{KI} / \mathrm{T} / \mathrm{L}-6 \mathrm{mice}$ revealed increased OCL numbers per bone surface area compared to wild-type (WT) mice. However, micro-quantitative CT ( $\mu Q C T$ ) analysis did not reveal significant differences between $p 62 \mathrm{KI} / \mathrm{T} / L-6$ and $\mathrm{WT}$ mice, and no pagetic OCLs or lesions were detected in vivo. Thus, increased IL- 6 expression in OCLs from $p 62 \mathrm{KI}$ mice contributes to increased responsivity to $1,25-(\mathrm{OH})_{2} \mathrm{D}_{3}$ and increased OCL numbers, but is not sufficient to induce Paget's-like OCLs or bone lesions in vivo. ( 2014 American Society for Bone and Mineral Research.
\end{abstract}

KEY WORDS: P62; MVNP; IL-6; PAGET'S DISEASE OF BONE; OSTEOCLASTS

\section{Introduction}

$\mathrm{T}$ he primary cellular abnormality in Paget's disease (PD) resides in the osteoclast $(\mathrm{OCL}){ }^{(1-3)} \mathrm{OCLs}$ are abundant in Paget's lesions, and are larger, contain increased nuclei/OCL, have increased bone resorbing capacity/OCL, increased 1,25dihydroxyvitamin $\mathrm{D}_{3}\left(1,25-(\mathrm{OH})_{2} \mathrm{D}_{3}\right)$ and receptor activator of NF$\kappa B$ ligand (RANKL) responsivity, and secrete high levels of interleukin 6 (IL-6), compared to normal OCLs. ${ }^{(4,5)}$ Pagetic OCLs frequently express the measles virus nucleocapsid protein $(\mathrm{MVNP}){ }^{(6)}$ which we have shown induces high levels of IL-6 expression in both human and mouse OCLs, and results in the development of pagetic OCLs and pagetic bone lesions in mice in vivo. ${ }^{(7,8)}$ Further, high levels of IL-6 can induce TAF12, a vitamin
D receptor (VDR) coactivator, in OCL precursors, which increases their responsivity to $1,25-(\mathrm{OH})_{2} \mathrm{D}_{3}$. Importantly, knockout of IL-6 in MVNP mice results in loss of their capacity to form pagetic lesions and $\mathrm{OCLs},{ }^{(9)}$ suggests that IL-6 is required for MVNP to induce the development of PD.

There is also a genetic component to the etiology of PD, with up to $5 \%$ to $10 \%$ of all Paget's patients carrying a germline mutation in the SQSTM1/p62 gene. ${ }^{(10)}$ Expression of $p 62^{P 392 L}$, the most frequent mutation in $p 62$ linked to $P D$ in $O C L$ precursors confers hyperresponsivity to RANKL but not $1,25-(\mathrm{OH})_{2} \mathrm{D}_{3}$, does not increase IL-6, and does not induce hypermultinucleated OCLs that occur in PD. Further, we found that knock-in mice (p62KI) carrying a $p 62^{P 394 L}$ mutation (the murine equivalent of the most common human PD mutation, $p 62^{P 392 L}$ ) had modestly increased

Received in original form October 2, 2013; revised form November 14, 2013; accepted November 25, 2013. Accepted manuscript online December 11, 2013. Address correspondence to: G David Roodman, MD, PhD, Department of Medicine, Hematology Oncology, School of Medicine, Indiana University, 980 West Walnut Street, R3, Indianapolis, IN 46202, USA. E-mail: groodman@iu.edu

Journal of Bone and Mineral Research, Vol. 29, No. 6, June 2014, pp 1456-1465

DOI: $10.1002 / j b m r .2158$

(C) 2014 American Society for Bone and Mineral Research 
OCL numbers and developed mild osteopenia, but did not develop pagetic lesions. ${ }^{(11,12)}$ However, when we crossed the p62KI and MVNP mice, the resulting $p 62 \mathrm{KI} / M V N P$ mice developed exuberant bone lesions that closely resembled PD lesions. ${ }^{(9)}$ In addition, $\mathrm{OCL}$ precursors isolated from $p 62 \mathrm{KI} / M V N P$ mice were hyperresponsive to both RANKL and $1,25-(\mathrm{OH})_{2} \mathrm{D}_{3}$, expressed elevated IL-6, and formed hypermultinucleated OCLs that were similar to $\mathrm{OCL}$ from PD patients. These results suggest that increasing IL-6 expression in OCLs of $p 62 \mathrm{KI}$ mice may induce pagetic lesions and a pagetic phenotype in p62KI mice in vivo.

To test this hypothesis, we generated transgenic mice overexpressing IL- 6 in OCLs driven by the tartrate-resistant acid phosphatase (TRAP) promoter (TIL-6 mice), and crossed them with the $p 62 \mathrm{KI}$ mice. OCL precursors from $p 62 \mathrm{KI} / \mathrm{TIL}-6$ mice were hyperresponsive to $1,25-(\mathrm{OH})_{2} \mathrm{D}_{3}$ and RANKL compared to wild-type (WT). However, although these OCL had increased numbers of nuclei/OCL, the nuclear number was lower than in MVNP mice. Further, p62KI/TIL-6 mice did not form pagetic OCLs or bone lesions in vivo.

PD is characterized by increases in both osteoclast and osteoblast activity; we found that both of these occur in MVNP but not the p62KI mice we generated. These results raise the question of why osteoblast activity is not induced in our previously reported $\mathrm{p} 62 \mathrm{KI}$ mice. We found that in contrast to MVNP mice, osteoblasts from $p 62 \mathrm{KI}$ mice expressed much lower levels of Runx2 and osterix, transcription factors necessary for osteoblast differentiation, and higher levels of Dickkopf 1 (DKK1), a Wnt antagonist. Treatment of osteoblast precursors from $p 62 \mathrm{KI}$ mice with IL-6 did not increase Runx2 or osterix and did not decrease DKK1 levels. These results suggest that MVNP expression in OCL induces other factors in addition to IL-6, which are necessary for the development PD lesions in mice.

\section{Subjects and Methods}

\section{Generation of TRAP-IL6 transgenic mice}

All studies were approved by the Institutional Animal Care and Use Committees at Indiana University School of Medicine, the University of Pittsburgh School of Medicine, and Virginia Commonwealth University. To generate the TRAP-IL-6 transgene construct, a 1.1-kb EcoRl endonuclease fragment containing a human IL-6 CDNA (ATCC cDNA number 67153; American Type Culture Collection [ATCC], Manassas, VA, USA) was inserted into the unique EcoRI site of the pKCR3-mTRAP vector. ${ }^{(13,14)}$ pKCR3mTRAP contains $1.9 \mathrm{~kb}$ of the mouse TRAP gene promoter and 5'untranslated region (UTR), in addition to rabbit $\beta$-globin intron 2 and its flanking exons (for efficient transgene expression). A 4.2$\mathrm{kb}$ injection fragment was then excised from the TRAP-IL-6 construct with Xhol restriction endonuclease, and transgenic mice were generated by standard methods in a CB6F1 (C57BI/ $6 \times$ Balb/c) genetic background. ${ }^{(15)}$ p62KI mice carrying a prolineto-leucine mutation at residue 394 (equivalent to human p62 ${ }^{P 392 L}$ ) have been described. ${ }^{(11)}$ TRAP-MVNP transgenic mice have also been described. ${ }^{(8)}$

\section{$\mathrm{OCL}$ formation from total transgenic mouse bone marrow}

Bone marrow cells flushed from long bones of WT, p62KI, TIL-6, p62KI/TIL-6, or MVNP mice were cultured in 96-well plates $\left(2 \times 10^{5}\right.$ cells/well) with various concentrations of $1,25-(\mathrm{OH})_{2} \mathrm{D}_{3}$ (Teijin Pharma, Tokyo, Japan) or RANKL (R\&D, Minneapolis, MN, USA) as described. The end of cultures, cells were stained for
TRAP using a leukocyte acid phosphatase kit (Sigma, St. Louis, MO, USA), and TRAP-positive cells ( $\geq 3$ nuclei/cell) were scored as OCLs.

\section{OCL formation from purified osteoclast precursors}

$\mathrm{OCL}$ formation from $\mathrm{CD}_{11} \mathrm{~b}^{+}$cells was performed as described. ${ }^{(16)}$ Nonadherent cells were harvested and enriched for $\mathrm{CD} 11 \mathrm{~b}^{+}$mononuclear cells using the Miltenyi Biotec (Auburn, CA, USA) MACS (Magnetic Cell Sorting) system. CD11 b ${ }^{+}$cells then were cultured in $\alpha$ modified essential medium ( $\alpha$-MEM) containing $10 \%$ fetal calf serum (FCS) plus $10 \mathrm{ng} / \mathrm{mL}$ of macrophage colony-stimulating factor (M-CSF; R\&D Systems, Minneapolis, MN, USA) for 3 days to generate a population of enriched early OCL precursors. These cells were then cultured in $\alpha$-MEM containing $10 \%$ FCS in the presence of $1,25-(\mathrm{OH})_{2} \mathrm{D}_{3}$ or RANKL for 3 to 4 days to generate OCLs. The cells were then stained for TRAP and TRAP-positive cells ( $\geq 3$ nuclei/cell) were scored as OCLs.

\section{Bone resorption assays of cultured OCLs}

Bone marrow cells were cultured on mammoth dentin slices (Wako, Osaka, Japan) in $\alpha$-MEM containing 10\% FCS and 1,25$(\mathrm{OH})_{2} \mathrm{D}_{3}\left(1 \times 10^{-8} \mathrm{M}\right)$ or RANKL $(100 \mathrm{ng} / \mathrm{mL})$. After 14 days of culture, the cells were removed, the dentin slices stained with acid hematoxylin, and the areas of dentin resorption determined using image-analysis techniques (NIH ImageJ System).

Immunoblotting of OCL precursor lysates from $\mathrm{WT}, \mathrm{p} 62 \mathrm{KI}$, $\mathrm{T} / L-6$, or $p 62 \mathrm{KI} / \mathrm{T} / L-6$ mice

Total proteins were extracted from formed $\mathrm{OCL}$ and loaded on SDS gels (Bio-Rad Laboratories, Hercules, CA, USA). Proteins were transferred to nitrocellulose membranes using a semidry blotter (Bio-Rad) and incubated in blocking solution (5\% nonfat dry milk in Tris-buffered saline Tween-20 [TBST]) for 1 hour. Membranes were then exposed to primary antibodies overnight at $4{ }^{\circ} \mathrm{C}$, and incubated with immunoglobulin $\mathrm{G}$ ( $\mathrm{lgG}$ ) horseradish peroxidase (HRP)-conjugated antibody for 1 hour. The blots were washed and visualized by an Immobilon Western Chemiluminescent detection system (Thermo).

\section{RANKL ELISA assay}

Mouse marrow stromal cells were isolated as described ${ }^{(11)}$ and cultured with $1,25-(\mathrm{OH})_{2} \mathrm{D}_{3}$ for 7 days. Conditioned media from these cultures were harvested at the end of the culture period and the concentration of RANKL present was determined using an ELISA kit for mouse RANKL (R\&D), according to the manufacturer's instructions.

\section{Quantitative microcomputed tomography measurements}

The gross morphologic and microarchitectural characteristics of the distal area of the femur and $L_{5}$ vertebra were examined by quantitative microcomputed tomography $(\mu C T)$. The $L_{5}$ vertebrae were used for microquantitative $C T$ ( $\mu \mathrm{QCT}$ ) to assess the trabecular bone, and the femurs were used to measure mean cortical thickness. A three-dimensional (3D) analysis was done to determine bone volume fraction (BV/TV, \%), trabecular number (Tb.N, N/ $\mu \mathrm{m}^{2}$ ), trabecular thickness (Tb.Th, $\mu \mathrm{m}$ ), and trabecular bone spacing (Tb.Sp, $\mu \mathrm{m}$ ). Cortical bone also was analyzed in the femur $2 \mathrm{~mm}$ below the growth plate, and the same segmentation parameters were used for analysis. 


\section{Bone histomorphometric analyses}

Mice were given calcein $(10 \mathrm{mg} / \mathrm{kg})$ on day 7 and day 2 prior to euthanasia. Lumbar vertebrae from WT, p62KI/TIL-6, or TIL-6 mice were subjected to qualitative histological examination and histomorphometry. The decalcified sections were stained for TRAP, and OCL containing active TRAP were stained red. The undecalcified sections were left unstained for the evaluation of fluorescent labels. The analysis was performed on the cancellous bone/marrow compartment between the cranial and caudal growth plates in the vertebral bodies without lesions using the OsteoMeasure XPTM version 1.01 morphometric programs (OsteoMetrics, Inc., Atlanta, GA, USA). Osteoclasts were defined as TRAP-positive mononuclear and multinuclear cells. Osteoclast surface (Oc.S/BS), cancellous bone volume (BV/TV), trabecular thickness (Tb.Th), trabecular number (Tb.N), trabecular separation (Tb.Sp), mineralizing surface (MS/BS), mineral apposition rate (MAR), and bone formation rate (BFR/BS) were analyzedcalculated and expressed-according to the recommendations of the ASBMR Nomenclature Committee. ${ }^{(17)}$

\section{Isolation of primary osteoblasts}

After flushing out the bone marrow from tibias and femora of p62KI, MVNP, and WT mice, the tibia and femurs were cultured in $\alpha$-MEM with $10 \%$ FCS for 7 to 10 days. The bones were then placed in $60-\mathrm{mm}$ dishes and the cultures were continued in $\alpha$ MEM containing 10\% FCS until cells growing out of the bones formed a confluent monolayer. The original bone was removed and the outgrowth cells from the bone were treated with $0.25 \%$ Trypsin and $0.05 \%$ EDTA for 10 minutes at $37^{\circ} \mathrm{C}$. These cells were used as primary osteoblasts without further passage. The primary osteoblasts ( $2 \times 10^{5}$ cells/well in six-well plates) were cultured in $\alpha$-MEM containing $10 \%$ FCS for 3 days and then IL- 6 or vehicle was added for 4 additional days. Cell lysates were collected with lysate buffer. This isolation method was previously used to establish the MC3T3-E1 cell line. ${ }^{(18)}$

\section{von Kossa staining}

Primary osteoblasts derived from WT, p62Kl, and MVNP mice were cultured in $10 \%$ FCS in $\alpha$-MEM for 3 weeks with the media changed every 3 days. The cells were then fixed with $10 \%$ formaldehyde in PBS, and stained with von Kossa stain as described. ${ }^{(19)}$

\section{Statistical analysis}

For all cell culture studies, significance was evaluated using a two-tailed unpaired Student's $t$ test, with $p<0.05$ considered to be significant.

\section{Results}

Characteristics of OCLs from WT, p62KI, TIL-6, p62KI/TIL-6, and MVNP mice

OCL precursors in total marrow cultures from MVNP mice, and to a lesser extent, $p 62 \mathrm{KI} / \mathrm{TIL}-6$ mice, were hyperresponsive to 1,25$(\mathrm{OH})_{2} \mathrm{D}_{3}$ compared to $p 62 \mathrm{KI}, \mathrm{T} / L-6$, and WT mice, and formed increased numbers of OCLs at $1 \times 10^{-10}$ to $1 \times 10^{-8} \mathrm{M} \mathrm{1,25-}$ $(\mathrm{OH})_{2} \mathrm{D}_{3}$ (Fig. $\left.1 A\right)$, suggesting that $p 62^{P 394 L}$ and $I L-6$ can cooperate to promote an increased osteoclastogenic response to 1,25$(\mathrm{OH})_{2} \mathrm{D}_{3}$. OCLs from MVNP and p62KI/TIL-6 mice (and to a lesser extent TIL-6 mice) also had increased numbers of nuclei per $\mathrm{OCL}$ when treated with $1,25-(\mathrm{OH})_{2} \mathrm{D}_{3}$, compared to those from WT and p62KI mice (Fig. $1 C, D$ ). OCL precursors in marrow cultures from MVNP, $p 62 \mathrm{KI} / \mathrm{T} / L-6$, and $p 62 \mathrm{KI}$ mice also formed increased numbers of OCLs with RANKL treatment compared to T/L- 6 and WT mice (Fig. 1B), suggesting that IL- 6 does not contribute significantly to RANKL responsivity. Bone resorption in response to $1,25-(\mathrm{OH})_{2} \mathrm{D}_{3}\left(1 \times 10^{-8} \mathrm{M}\right)$ and RANKL $(100 \mathrm{ng} / \mathrm{mL})$ was comparable in marrow cultures from MVNP and p62KI/TIL6 mice, which were $>$ p62KI $>$ TIL-6 $>$ WT (Fig. 1E).

\section{$\mathrm{OCL}$ formation by highly purified populations of $\mathrm{OCL}$ precursors}

$\mathrm{OCL}$ formation assays by highly purified populations of $\mathrm{OCL}$ precursors showed that only OCL precursors from TIL-6, p62KI/ TIL-6, and MVNP mice were hyperresponsive to $1,25-(\mathrm{OH})_{2} \mathrm{D}_{3}$, compared to WT and p62KI derived cultures (Fig. $2 A$ ), demonstrating that the increased $1,25-(\mathrm{OH})_{2} \mathrm{D}_{3}$ responsivity seen in total marrow cultures from the $p 62 \mathrm{KI}$ mice (Fig. $1 A$ ) resulted from effects of stromal cells in these cultures. However, the relative OCL formation in response to RANKL by pure populations of OCL precursors was identical to that from the total marrow cultures; ie, OCL precursors from $p 62 \mathrm{KI}, p 62 \mathrm{KI} / \mathrm{T} / L-6$, and MVNP and mice were hyperresponsive to RANKL compared to those from TIL-6 or WT mice (Fig. 2B). The nuclear number per OCL also showed the same pattern of results as seen in OCLs formed from whole marrow cultures (Fig. 2C). These results are consistent with our previous results showing that mutant p62 contributes to RANKL hyperresponsivity directly in OCLs, whereas its contribution to increased $1,25-(\mathrm{OH})_{2} \mathrm{D}_{3}$ responsivity is mediated through effects on stromal cells. ${ }^{(11)}$ In contrast, IL-6 contributes to $1,25-(\mathrm{OH})_{2} \mathrm{D}_{3}$ responsivity directly in OCLs, but does not appear to have an affect on OCL response to RANKL.

We recently reported that IL-6 induces expression of TAF12, a novel coactivator of VDR-mediated transcription that is increased in OCLs from PD patients and MVNP mice. ${ }^{(20)}$ Therefore, we determined if TAF12 expression was increased in OCLs from p62KI, TIL-6, and p62KI/TIL-6 mice. OCLs formed by highly purified OCL precursors from TIL- 6 and $p 62 \mathrm{KI} / \mathrm{TIL}-6$ mice expressed elevated levels of TAF12 compared to WT (Fig. 2D). In contrast, TAF12 was not increased in OCLs from $p 62 \mathrm{KI}$ mice.

RANKL expression by marrow stromal cells derived from WT, p62KI, T/L-6, p62KI/TIL-6, and MVNP mice

We previously found that marrow stromal cells from $p 62 \mathrm{KI}$ but not MVNP mice have increased expression of TAF12 which resulted in enhanced RANKL production by the stromal cells when treated with low concentrations of $1,25-(\mathrm{OH})_{2} \mathrm{D}_{3} \cdot{ }^{(7,8)}$ Therefore, we measured RANKL production by stromal cells from $p 62 \mathrm{KI}, \mathrm{TIL}-6, p 62 \mathrm{KI} / \mathrm{TIL}-6, M V N P$, and WT mice. Stromal cells from $p 62 \mathrm{KI} / \mathrm{T} / L-6$ and $p 62 \mathrm{KI}$ mice treated with $1,25-(\mathrm{OH})_{2} \mathrm{D}_{3}$ produced increased levels of RANKL when treated with

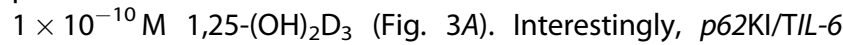
stromal cells produced twofold more secreted RANKL than $p 62 \mathrm{KI}$ stromal cells (Fig. 3B). Both the RANKL/osteoprotegerin (OPG) ratio (Fig. $3 A$ ) and TAF12 levels (Fig. $3 C$ ) were markedly increased in stromal cells from $p 62 \mathrm{KI} / \mathrm{T} / L-6$ mice but not in MVNP mice. These results demonstrate that high levels of IL- 6 produced by TIL-6 mice also induce TAF12 in marrow stromal cells, which enhances their responsivity to $1,25-(\mathrm{OH})_{2} \mathrm{D}_{3}$ and results in increased RANKL production by stromal cells from p62KI/TIL-6 mice treated with $1,25-(\mathrm{OH})_{2} \mathrm{D}_{3}$. 

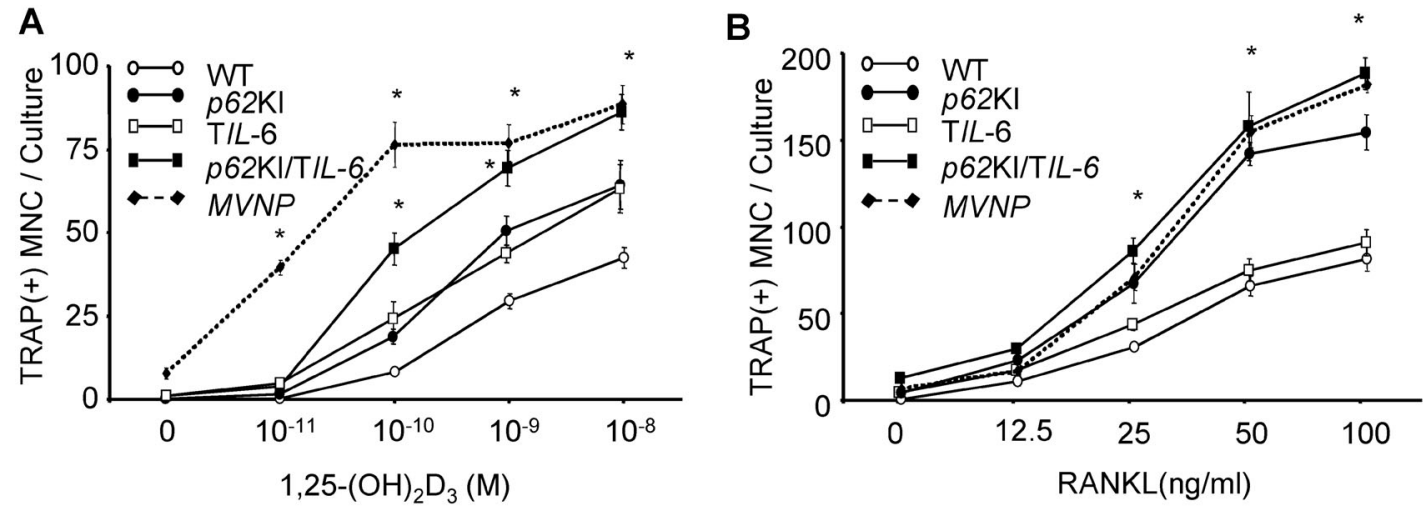

C
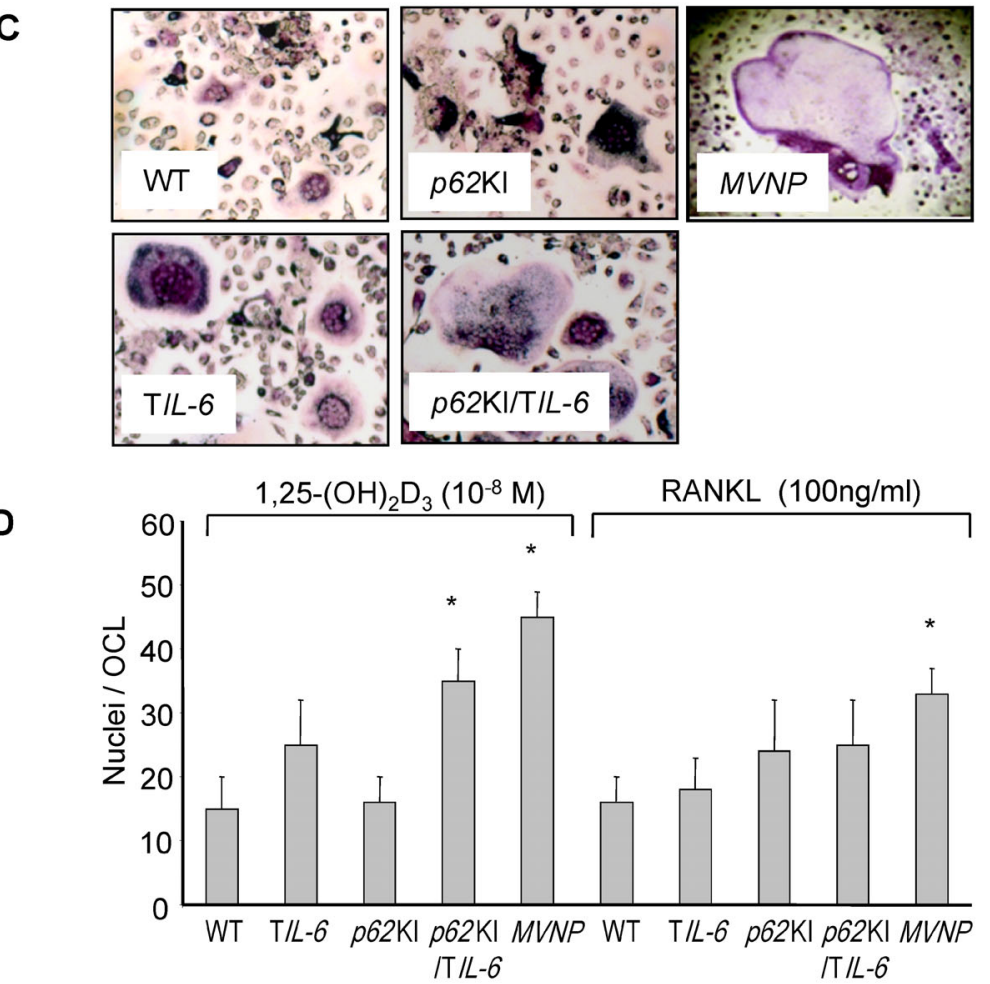

E

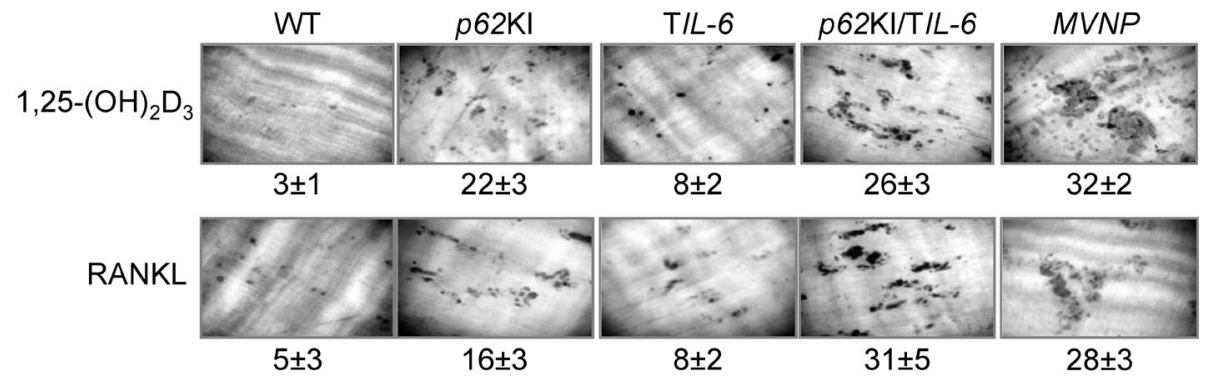

Fig. 1. Osteoclast formation in whole bone marrow cultures from WT, $p 62 \mathrm{KI}, \mathrm{T} / L-6, p 62 \mathrm{KI} / \mathrm{TIL}-6$, and MVNP mice. (A) OCL formation by treatment of $1,25-$ $(\mathrm{OH})_{2} \mathrm{D}_{3}$. Data are expressed as the mean $\pm \mathrm{SD}(n=4) ;{ }^{*} p<0.01$, significantly different from OCLs formed with the same treatment in WT mouse cultures. (B) OCL formation by treatment of RANKL. Data are expressed as the mean $\pm \mathrm{SD}(n=4)$; $^{*} p<0.01$, significantly different from OCLs formed with the same treatment in WT mouse cultures. (C) Phenotype of OCLs formed from mouse bone marrow cultures. OCLs formed by $1,25-(\mathrm{OH})_{2} \mathrm{D}_{3}\left(1 \times 10^{-8} \mathrm{M}\right)$ were stained for TRAP. Magnification $\times 100$. (D) Nuclei per OCL. The nuclear numbers per OCL were randomly counted in 25 OCLs formed in $1 \times 10^{-8} \mathrm{M} 1,25-$ $(\mathrm{OH})_{2} \mathrm{D}_{3}$ or $100 \mathrm{ng} / \mathrm{mL}$ RANKL-treated cultures as in $A$ and $B$. Data are expressed as the mean $\pm \mathrm{SD}(n=25) ;{ }^{*} p<0.01$, significantly different from OCLs formed with the same treatment in WT mouse cultures. (E) Bone resorption capacity of OCLs. Bone marrow cells were cultured for 7 days with $1,25-(\mathrm{OH})_{2} \mathrm{D}_{3}$ $\left(1 \times 10^{-8} \mathrm{M}\right)$ or RANKL $(100 \mathrm{ng} / \mathrm{mL})$ on mammoth dentin slices. Values represent the amount of dentin surface resorption (\%), mean $\pm \mathrm{SD}(n=4)$. $\mathrm{WT}=$ wild $=$ type; $\mathrm{OCL}=$ osteoclast $; 1,25-(\mathrm{OH})_{2} \mathrm{D}_{3}=1,25$-dihydroxyvitamin $\mathrm{D}_{3} ; \mathrm{TRAP}=$ tartrate-resistant acid phosphatase; $\mathrm{RANKL}=$ receptor activator of NF-кB ligand. 
A

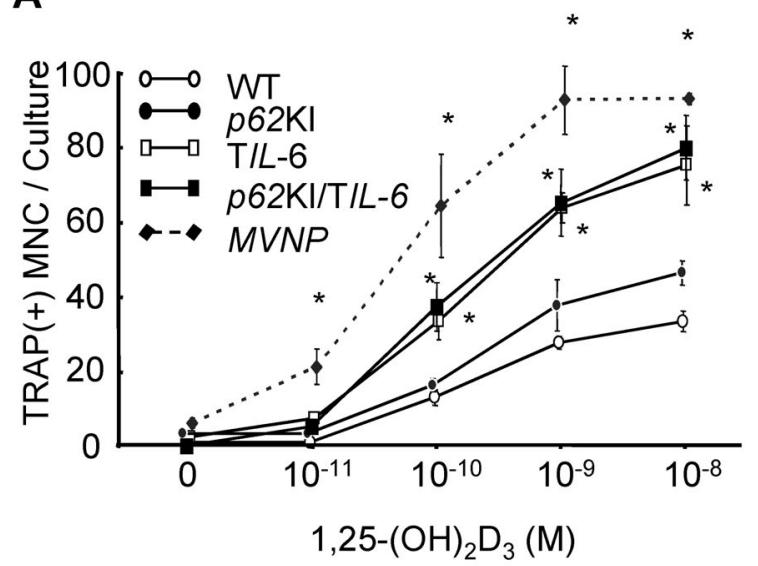

B

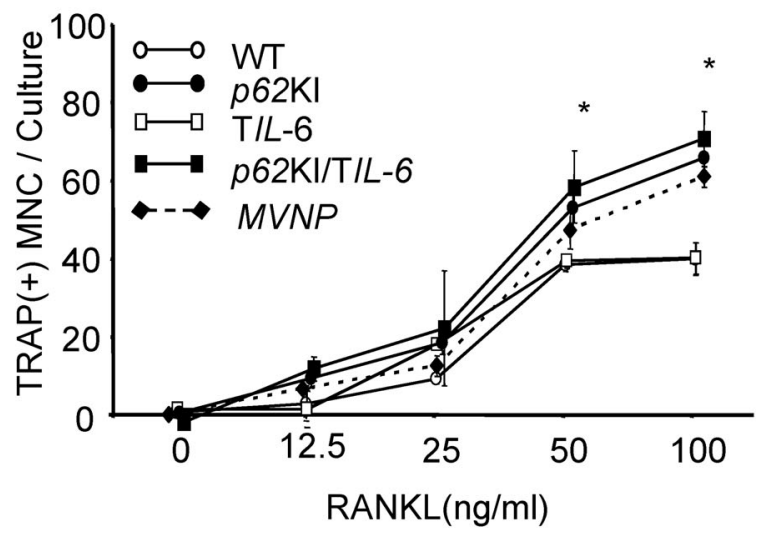

C

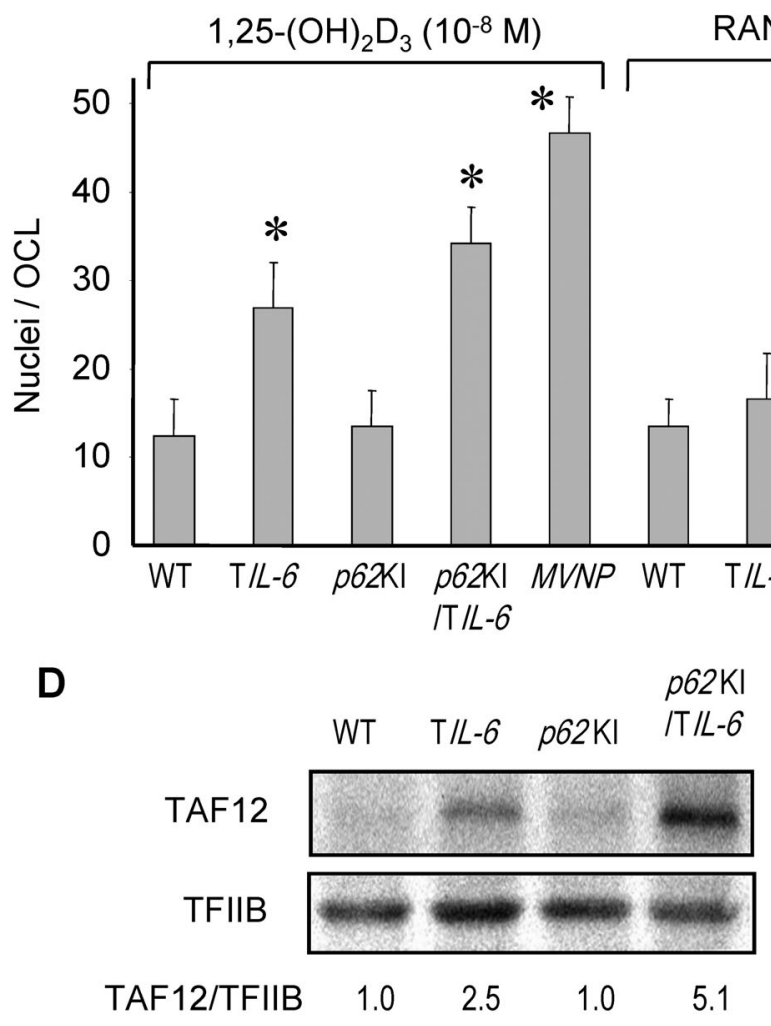

Fig. 2. Osteoclast formation formed by $C D 11 b^{+}$cells from WT, p62KI, T/L-6, p62KI/T/L-6, and MVNP mice. (A) OCL formation by $1,25-(\mathrm{OH})_{2} \mathrm{D}_{3}$. Data are expressed as the mean $\pm \mathrm{SD}(n=4) ;{ }^{*} p<0.01$, significantly different from OCLs formed with the same treatment in WT mouse cultures. (B) OCL formation by RANKL. Data are expressed as the mean $\pm \mathrm{SD}(n=4) ;{ }^{*} p<0.01$, significantly different from OCLs formed with the same treatment in WT mouse cultures. (C) Nuclei per OCL. The nuclear number per OCL was determined by randomly scoring $25 \mathrm{OCLs}$ formed in $\left.1 \times 10^{-8} \mathrm{M} \mathrm{1,25-(OH)}\right)_{2} \mathrm{D}_{3}$ or $100 \mathrm{ng} / \mathrm{mL}$ of RANKLtreated cultures. Data are expressed as the mean $\pm \mathrm{SD}(n=25) ;{ }^{*} p<0.01$, significantly different from OCLs formed with the same treatment in WT mouse cultures. (D) TAF12 expression in OCLs. CD11 b $\mathrm{b}^{+}$mononuclear cells were treated with $10 \mathrm{ng} / \mathrm{mL}$ of M-CSF for 3 days, then cultured with RANKL (100 $\mathrm{ng} / \mathrm{mL}$ ) for 4 days and cell lysates were collected. TAF12 expression was analyzed by immunoblot using antibodies recognizing TAF12 (ProteinTech). TFIIB was used as a loading control. WT $=$ wild-type; $R A N K L=$ receptor activator of NF- $\mathrm{KB}$ ligand; $\mathrm{OCL}=$ osteoclast; $1,25-(\mathrm{OH})_{2} \mathrm{D}_{3}=1,25$-dihydroxyvitamin $\mathrm{D}_{3}$; $\mathrm{M}-\mathrm{CSF}=$ macrophage colony-stimulating factor; TFIIB $=$ transcription factor IIB.

Next we examined if WT, p62KI, TIL-6, p62KI/TIL-6, and MVNP stromal cells differentially supported OCL formation. Stromal cells were cocultured with colony-forming unit-granulocytemacrophage (CFU-GM)-derived cells (OCL precursors) from WT mice with $1 \times 10^{-8} \mathrm{M} 1,25-(\mathrm{OH})_{2} \mathrm{D}_{3}$ or vehicle for 7 days.
As shown in Fig. 3D, stromal cells derived from p62KI/TIL-6 mice, and to a lesser extent $p 62 \mathrm{KI}$ mice, had an increased capacity to support $O C L$ formation in response to 1,25 $(\mathrm{OH})_{2} \mathrm{D}_{3}$. Because stromal cells from MVNP mice do not express increased TAF12, they did not increase OCL formation 
A

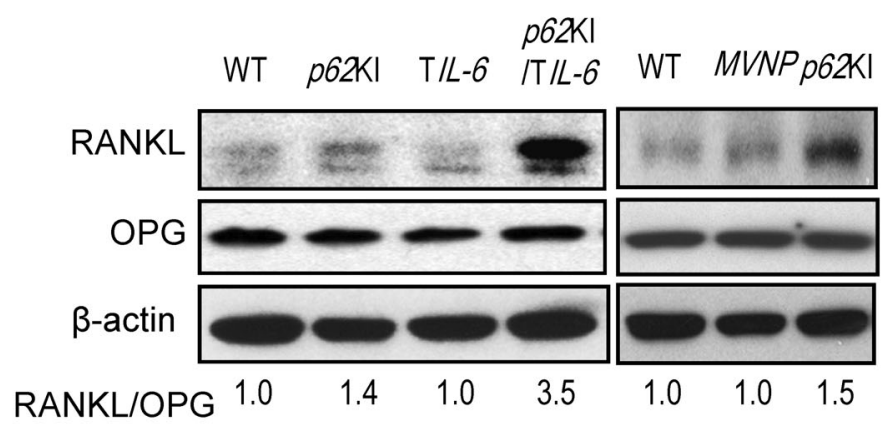

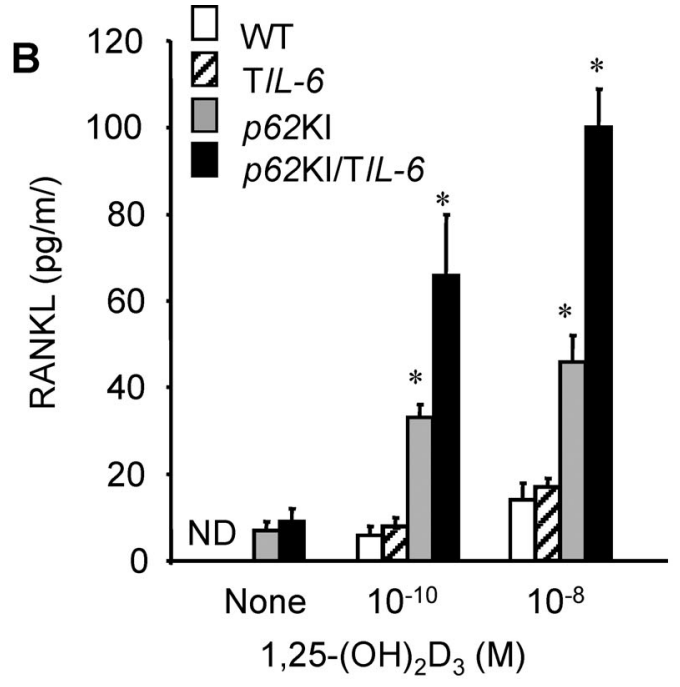

C p62KI

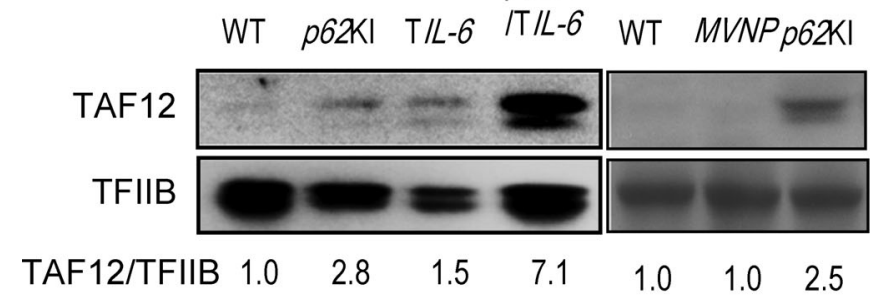

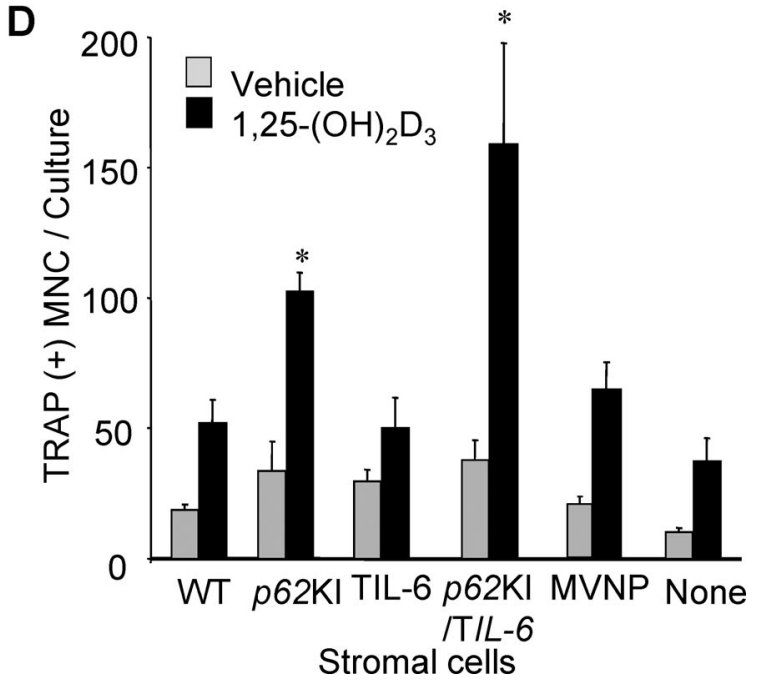

Fig. 3. Support of OCL formation by marrow stromal cells from WT, p62KI, T/L-6, p62KI/TIL-6, and MVNP mice. (A) RANKL and OPG expression. Stromal cells from WT, p62KI, T/L-6, p62KI/TIL-6, and MVNP mice were cultured with $1,25-(\mathrm{OH})_{2} \mathrm{D}_{3}\left(1 \times 10^{-8} \mathrm{M}\right)$ for 2 days, the cell lysates were collected, and the levels of RANKL and OPG were determined by Western blot analysis using anti-RANKL and anti-OPG antibodies (Santa Cruz Biotechnology, Santa Cruz, CA, USA). The ratio of RANKL/OPG expression levels from Western blots were quantitated by densitometry using WT cultures as 1.0. (B) RANKL production by mouse marrow stromal cells. Mouse marrow stromal cells were cultured with $1,25-(\mathrm{OH})_{2} \mathrm{D}_{3}$ for 7 days. Conditioned media from these cultures were harvested at the end of the culture period and the concentration of RANKL present was determined. The data is shown as mean $\pm \operatorname{SD}(n=4) ;{ }^{*} p<0.01$ compared with WT cells cultured with the same concentration of $1,25-(\mathrm{OH})_{2} \mathrm{D}_{3}$. (C) TAF12 expression in marrow stromal cells. Stromal cells were cultured with $10 \%$ FCS in IMDM for 3 days and then cell lysates were collected. TAF12 expression was analyzed by immunoblot using a polyclonal antibody recognizing TAF12. TFIIB was used as a loading control. (D) Support of OCL formation by marrow stromal cells. Stromal cells from WT, $p 62 \mathrm{Kl}, \mathrm{T} / L-6, p 62 \mathrm{KI} / \mathrm{TIL}-6$, and $M V N P$ mice were cocultured with CFU-GM derived from WT mouse bone marrow in the presence of $1 \times 10^{-8} \mathrm{M} 1,25-(\mathrm{OH})_{2} \mathrm{D}_{3}$ for 7 days. The cells were then fixed and stained for TRAP, and the TRAP-positive OCLs were counted. Results are expressed as the mean $\pm \mathrm{SD}(n=4)$; ${ }^{*} p<0.01$ compared with results in WT cultures. $\mathrm{OCL}=$ osteoclast; $\mathrm{WT}=$ wild-type; $\mathrm{RANKL}=$ receptor activator of NF- $\mathrm{KB}$ ligand; $\mathrm{OPG}=$ osteoprotegerin; $1,25-(\mathrm{OH})_{2} \mathrm{D}_{3}=1,25-$ dihydroxyvitamin $\mathrm{D}_{3} ; \mathrm{FCS}=$ fetal calf serum; IMDM = Iscove's Modified Dulbecco's Media; TFIIB = transcription factor IIB; CFU-GM=colony-forming unit-granulocytemacrophage; TRAP $=$ tartrate-resistant acid phosphatase.

when cocultured with WT OCL precursors treated with 1,25$(\mathrm{OH})_{2} \mathrm{D}_{3}$ (Fig. 3D).

\section{Bone phenotype of $p 62 \mathrm{KI} / \mathrm{T} / L-6$ mice}

To determine whether coexpression of mutant $p 62$ and IL- 6 in the bone promote the development of pagetic lesions, we examined lumbar vertebral bone from $p 62 \mathrm{KI}, \mathrm{TIL}-6, \mathrm{p} 62 \mathrm{KI} / \mathrm{TIL}-6$, and WT mice at 12 months of age by qualitative histology and histomorphometry, and femurs and $L_{5}$ vertebra by $\mu C T$. No pagetic lesions were found in the lumbar vertebrae of any of these mice. Further, $\mu \mathrm{QCT}$ histomorphometric analysis revealed no significant differences between mice of any of the four genotypes in bone structural variables (cancellous BV/TV, Tb.N, Tb.Wi, Tb.Sp) (Table 1), nor in the mineralized surface (Md.Pm), MAR, and BFR (Fig. 4). Only OCL numbers per bone surface were significantly increased in both $p 62 \mathrm{KI}$ and $p 62 \mathrm{KI} / \mathrm{TIL}-6$ mice (Fig. 4). 
Table 1. Structural Histomorphometric Variables of WT, T/L-6, p62KI, and p62KI/TIL-6 Mice

\begin{tabular}{|c|c|c|c|c|c|c|c|c|}
\hline & \multicolumn{4}{|c|}{ Male } & \multicolumn{4}{|c|}{ Female } \\
\hline & $\begin{array}{c}\text { WT } \\
(n=7)\end{array}$ & $\begin{array}{c}\text { TIL-6 } \\
(n=7)\end{array}$ & $\begin{array}{l}p 62 \mathrm{KI} \\
(n=6)\end{array}$ & $\begin{array}{c}p 62 \mathrm{KI} / \mathrm{T} I L-6 \\
(n=3)\end{array}$ & $\begin{array}{c}\mathrm{WT} \\
(n=7)\end{array}$ & $\begin{array}{c}\text { TIL-6 } \\
(n=10)\end{array}$ & $\begin{array}{l}p 62 \mathrm{KI} \\
(n=7)\end{array}$ & $\begin{array}{c}p 62 \mathrm{KI} / \mathrm{TIL}-6 \\
(n=10)\end{array}$ \\
\hline BV/TV (\%) & $13.4 \pm 2.1$ & $13.1 \pm 5.9$ & $13.5 \pm 5.8$ & $14.6 \pm 4.5$ & $13.3 \pm 5.6$ & $11.9 \pm 4.3$ & $10.2 \pm 2.5$ & $11.2 \pm 3.9$ \\
\hline Tb.Th $(\mu \mathrm{m})$ & $31.4 \pm 3.1$ & $33.1 \pm 5.6$ & $36.2 \pm 8.5$ & $33.1 \pm 5.0$ & $33.3 \pm 4.5$ & $35.5 \pm 5.3$ & $35.5 \pm 3.6$ & $37.1 \pm 9.8$ \\
\hline Tb.N $\left(1 / \mathrm{mm}^{2}\right)$ & $4.3 \pm 0.4$ & $3.8 \pm 1.1$ & $3.7 \pm 1.3$ & $4.4 \pm 0.9$ & $4.0 \pm 1.6$ & $3.5 \pm 1.7$ & $2.9 \pm 0.6$ & $3.0 \pm 0.1$ \\
\hline Tb.Sp $(\mu \mathrm{m})$ & $204.4 \pm 22.3$ & $248.1 \pm 86.0$ & $265.4 \pm 121.9$ & $203.0 \pm 48.1$ & $239.6 \pm 73.0$ & $312.0 \pm 169.1$ & $327.1 \pm 84.3$ & $313.0 \pm 84.2$ \\
\hline
\end{tabular}

Structural variables for the lumbar vertebral bodies from 12-month-old WT, $p 62 \mathrm{KI}, \mathrm{T} / L-6$, and $p 62 \mathrm{KI} / \mathrm{T} / \mathrm{L}-6$ mice. Data are expressed as mean \pm SD. No significant differences between WT and other mice in all the variables.

$\mathrm{WT}=$ wild-type; $\mathrm{BV} / \mathrm{TV}=$ cancellous bone volume; $\mathrm{Tb} . \mathrm{Th}=$ trabecular thickness; $\mathrm{Tb} . \mathrm{N}=$ trabecular number; $\mathrm{Tb} . \mathrm{Sp}=$ trabecular separation.

\section{Expression of $\mathrm{OCL}$ fusion molecules in $\mathrm{OCL}$ precursors}

Because OCL precursors from MVNP mice and pagetic patients expressing MVNP form OCLs with increased nuclei per $O C L$, we measured the expression levels of several fusion molecules in MVNP, p62KI, and WT OCL precursors treated with IL-6 for 4 days. OCLs formed from MVNP mice with or without IL-6 treatment had elevated expression of dendritic cell-specific transmembrane protein (DC-STAMP) compared with those from p62KI and WT mice (Fig. 5). The expression levels of the $d 2$ isoform of the $v$ ATPase V0 domain (ATP6v0d2) and a distintegrin and a metalloproteinase domain-8 (ADAM8) were only modestly elevated in MVNP OCL (Fig. 5).

\section{Effect of IL-6 on osteoblast differentiation}

Our previous data demonstrated that IL- 6 was required to increase bone formation and induce a pagetic phenotype in MVNP mice. ${ }^{(4)}$ It was thus our hypothesis that increasing IL-6 expression in OCLs of $p 62 \mathrm{KI}$ mice would result in development of a pagetic bone lesions in $p 62 \mathrm{KI} / \mathrm{T} / L-6$ mice. We therefore examined the effects of IL- 6 on osteoblast differentiation by primary osteoblasts from $p 62 \mathrm{KI}, M V N P$, and WT mice.

We found that there was a twofold increase in the levels of Runx2 and Osterix in osteoblasts from MVNP mice compared with WT and p62KI mice. These parameters were not affected by IL- 6 treatment of WT, MVNP, or p62KI osteoblasts (Fig. $6 A$ ). In contrast, IL-6 treatment of MVNP osteoblasts modestly enhanced alkaline phosphatase (ALP) expression. The levels of osteocalcin expression were not different in WT, p62KI, and MVNP osteoblasts and IL- 6 did not increase osteocalcin expression (Fig. 6A). Because high expression levels of Dickkopf 1 (Dkk1) can inhibit osteoblast differentiation, ${ }^{(21)}$ we measured Dkk1 levels in $\mathrm{WT}$, p62Kl, and MVNP osteoblasts. Dkk1 expression in p62KI osteoblasts was elevated twofold and increased to 3.8-fold with IL-6 treatment (Fig. 6A). In contrast, MVNP and WT osteoblasts had much lower levels of Dkk1 that were not affected by IL-6 treatment (Fig. 6A). Osteoblast (OB)cadherin and ALP were decreased in the $p 62 \mathrm{KI}$ mice compared to WT and MVNP, and were inversely correlated with Dkk1 expression, which was elevated in p62KI compared to WT and MVNP; RUNX2 and osterix were induced twofold in MVNP mice.
A

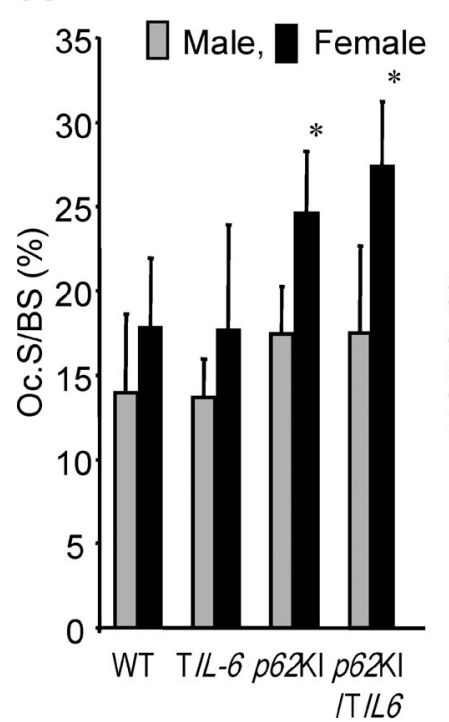

B

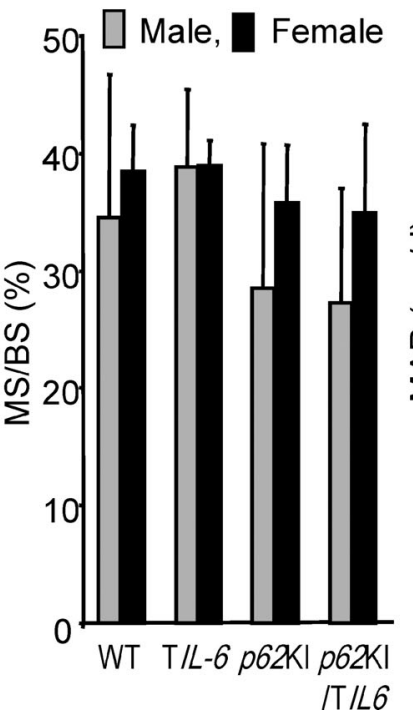

C

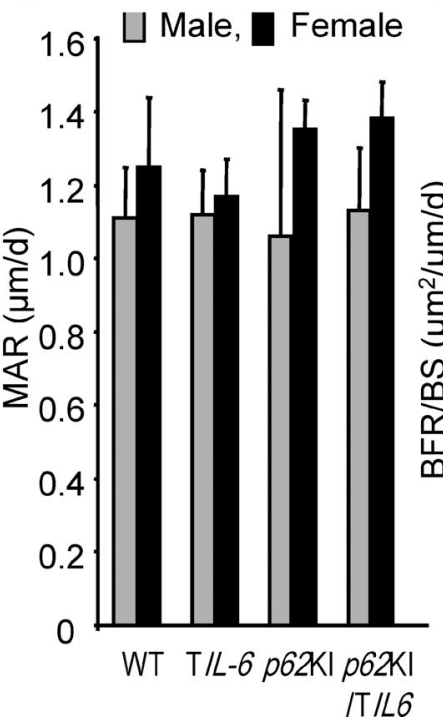

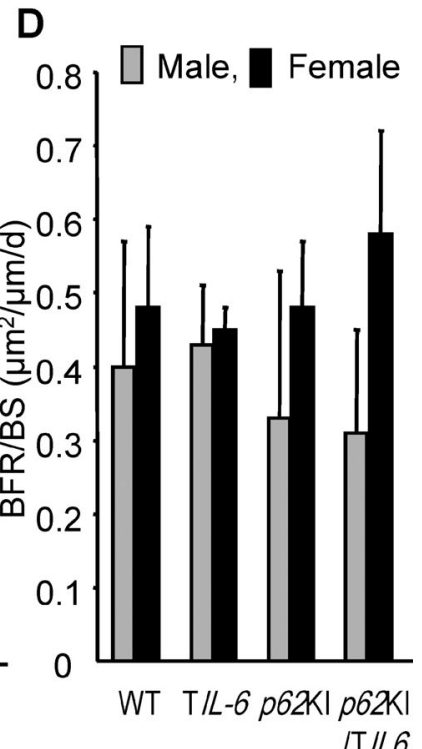

Fig. 4. Histomorphometric analysis of $\mathrm{WT}, \mathrm{T} / L-6, p 62 \mathrm{Kl}$, and $p 62 \mathrm{KI} / \mathrm{T} / \mathrm{L}-6$ lumbar vertebra from 12 -month-old. (A) OC.Pm, (B) Md.Pm, (C) MAR, and (D) BFR for WT, TIL-6, p62KI, and p62KI/TIL-6 mice are shown. Data represent mean \pm SD for WT (7 male, 7 female), p62KI (6 male, 7 female), T/L-6 (7 male, 10 female), and $p 62 \mathrm{KI} / \mathrm{T} / L-6$ (3 male, 10 female) mice per group. ${ }^{*} p<0.01$ significant differences between WT and $p 62 \mathrm{KI} / T / L-6$ mice were detected. WT $=$ wild-type; $\mathrm{OCL}=$ osteoclast; $\mathrm{OC} . \mathrm{Pm}=\mathrm{OCL}$ surface; $\mathrm{Md} . \mathrm{Pm}=$ mineralized surface; $\mathrm{MAR}=$ mineral apposition rate; $\mathrm{BFR}=$ bone formation rate. 


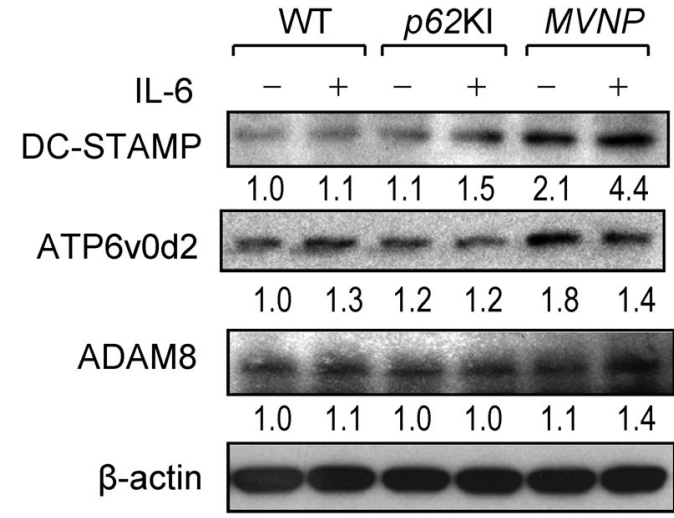

Fig. 5. The expression of fusion molecules in WT, p62Kl, and MVNP OCL precursors. $\mathrm{CD} 11 \mathrm{~b}^{+}$mononuclear cells were treated with $10 \mathrm{ng} / \mathrm{mL} M-$ CSF for 3 days, then treated with or without mouse IL-6 (10 ng/mL) (R\&D) and mouse IL-6 receptor $(10 \mathrm{ng} / \mathrm{mL})(\mathrm{R} \& D)$ for 4 days. Cell lysates were analyzed by immunoblot using antibodies recognizing DC-STAMP (Cosmo Bio Co. Ltd, Tokyo, Japan), ATP6v0d2 (Abnova Co., Taipei, Taiwan), ADAM8 (Santa Cruz Biotechnology, Santa Cruz, CA, USA), and $\beta$ actin (Abcam, Cambridge, MA, USA) as a loading control. WT = wild-type; $\mathrm{OCL}=$ osteoclast; $\mathrm{M}-\mathrm{CSF}=$ macrophage colony-stimulating factor; IL$6=$ interleukin 6 ; DC-STAMP $=$ dendritic cell-specific transmembrane protein; $A T P 6 v 0 d 2=$ the $d 2$ isoform of the $v$-ATPase V0 domain; $A D A M 8=$ a distintegrin and a metalloproteinase domain-8.

We then measured the mineral deposition capacity of the osteoblasts by von Kossa staining. MVNP osteoblast cultures showed increased numbers of calcified areas compared with cultures of p62KI and WT osteoblasts (Fig. 6B). These results suggest that the osteoblast differentiation capacity of osteoblast from $p 62 \mathrm{KI}$ mice is much lower than osteoblast from MVNP mice.

\section{Discussion}

Both environmental elements and genetic causes both contribute to PD. We found that the expression of both MVNP and the SQSTM1 (p62) mutation P392L in OCLs contribute to the increased $\mathrm{OCL}$ activity in $\mathrm{PD}$, and we have reported that p62 ${ }^{\mathrm{P} 392 \mathrm{~L}}$ knock-in mice do not develop pagetic lesions unless MVNP is also present. When MVNP is present with the p62KI mutation, mice develop exuberant pagetic lesions very similar to those seen in patients with PD of bone. However, Daroszewska and colleagues ${ }^{(22)}$ reported that a similar p62 ${ }^{\text {P394L }}$ knock-in mouse develops small focal lesions which showed increases in bone turnover with increased bone resorption and formation, disruption of the normal bone architecture, and an accumulation of woven bone. The basis for the differences in these two knockin models is unclear at this time but demonstrate that the capacity of mutant p62 to induce pagetic lesions in vivo is variable. MVNP, but not $p 62 \mathrm{KI}$, mice have increased IL-6 production and loss of IL- 6 blocks the effects of MVNP in PD. ${ }^{(9,11,12)}$ These results suggest $p 62 \mathrm{KI}$ in combination with high IL- 6 in OCL may result in PD. To address this question, we generated $p 62 \mathrm{KI} / \mathrm{T} / L-6$ transgenic mice by breeding $p 62 \mathrm{KI}$ mice to TIL-6 mice in which overexpression of IL- 6 is driven by the TRAP promoter, and characterized their OCLs and bone phenotype.

$\mathrm{OCL}$ precursors from $p 62 \mathrm{KI} / \mathrm{TIL}-6$ mice formed $\mathrm{OCL}$ that expressed an intermediate pagetic phenotype in vitro (Fig. 1).
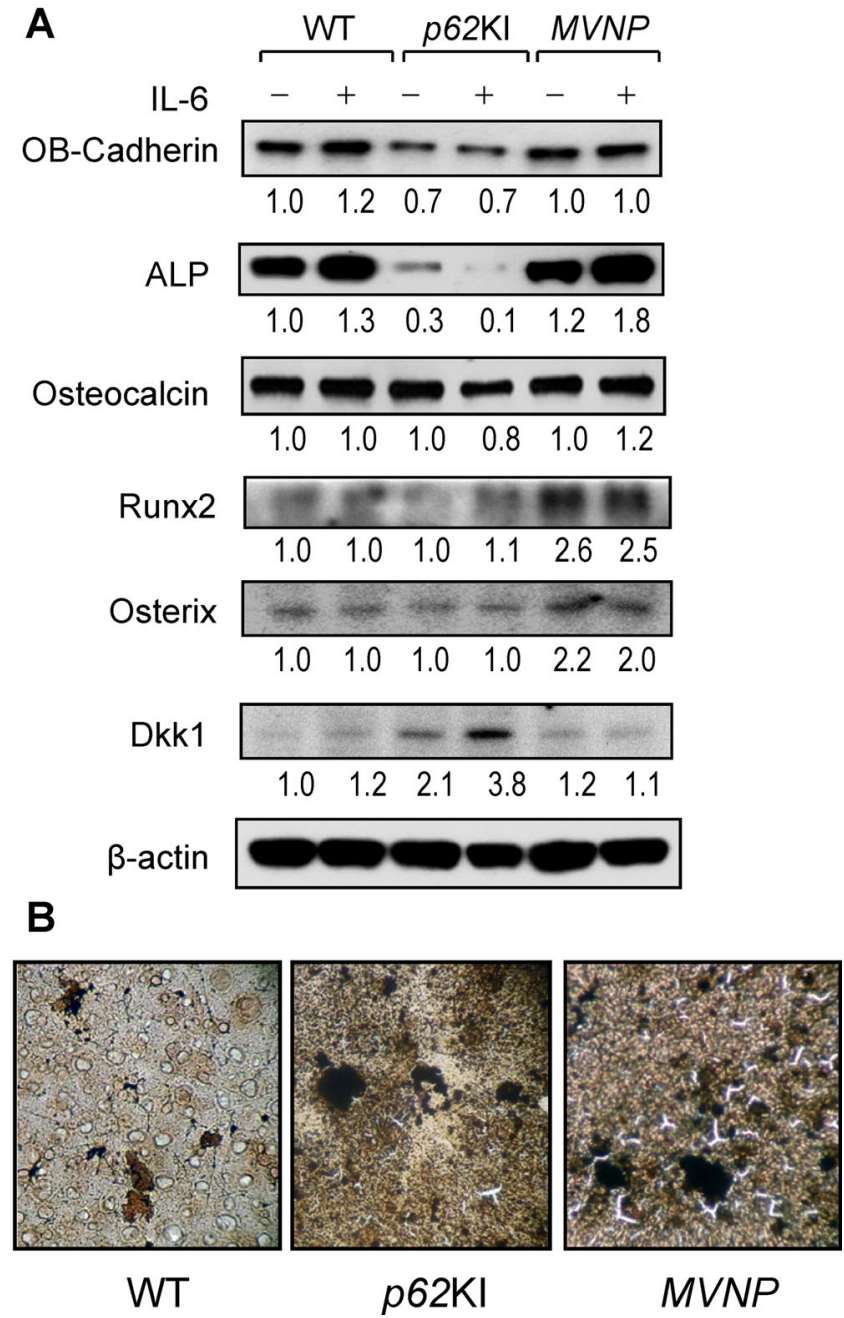

Fig. 6. Osteoblast differentiation markers in osteoblasts derived from WT, p62KI, and MVNP mice. (A) Expression of osteoblast differentiation markers. Primary osteoblasts $\left(2 \times 10^{5}\right.$ cells $/ 35-\mathrm{mm}$ dish) were cultured with or without $10 \mathrm{ng} / \mathrm{mL}$ of IL- 6 for 4 days in $10 \%$ FCS in $\alpha$-MEM. Cell lysates were analyzed by immunoblot using antibodies recognizing $O B-$ Cadherin (Cell Signaling, Beverly, MA, USA), alkaline phosphatase (Millipore, Billerica, MA, USA), Runx2 (Santa Cruz Biotechnology, Santa Cruz, CA, USA), Osterix (Abcam, Cambridge, MA, USA), osteocalcin (Millipore), Dkk1 (Cell Signaling), and $\beta$-actin (Abcam) as loading control. (B) Calcification in vitro. Osteoblasts were cultured in $10 \%$ FCS with $\alpha$ MEM for 3 weeks as described in Subjects and Methods. The cells were stained with von Kossa stain $(\times 100)$. WT = wild-type; IL-6 = interleukin 6; $\mathrm{FCS}=$ fetal calf serum; $\alpha-M E M=\alpha$ modified essential medium.

The OCLs were hyperresponsive to $1,25-(\mathrm{OH})_{2} \mathrm{D}_{3}$ and RANKL, formed $\mathrm{OCL}$ with increased bone resorbing capacity and elevated levels of TAF12 but developed only modest multinuclearity (Figs. 1, 2) compared to MVNP mice.

In contrast, $\mathrm{OCL}$ precursors from $p 62 \mathrm{KI}$ and WT mice were not hyperresponsive to $1,25-(\mathrm{OH})_{2} \mathrm{D}_{3}$, expressed normal levels of TAF12, and formed normal OCLs. ${ }^{(11)}$ Only OCL precursors from p62KI/TIL-6 were hyperresponsive to RANKL, whereas both p62KI/TIL-6 and TIL-6 cells had increased STAT3 signaling (Fig. 2D). p62KI and WT OCL had normal ratios of nuclei/OCL when treated with $1,25-(\mathrm{OH})_{2} \mathrm{D}_{3}$ or RANKL. These results 
suggested that expression of IL- 6 in p62KI OCL precursors is required for OCLs to express a pagetic phenotype in vitro, and that high levels of IL- 6 enhances $\mathrm{OCL}$ precursor fusion in $p 62 \mathrm{KI}$ mice. The enhanced OCL precursor fusion in MVNP mice most likely reflects the increased expression of DC-STAMP ${ }^{(23,24)}$ in their OCL precursors, which was enhanced by IL-6 treatment (Fig. 5). DC-STAMP appears to be increased selectively in MVNP OCL precursors compared with other fusion molecules associated with increased $\mathrm{OCL}$ precursor fusion (eg, D44, CD48, and ADAM8), and was not increased significantly in p62KI and WT $\mathrm{OCL}$ precursors (Fig. 5). Lee and colleagues ${ }^{(25)}$ reported that increased nuclear factor of activated T cells, cytoplasmic 1 (NFATC1) through upregulation of c-Fos increased expression of DC-STAMP. Because IL- 6 increases expression of c-Fos and NFATc1, this may explain its capacity to enhance DC-STAMP expression. ATP6v0d2 also was upregulated modestly (1.8-fold) in MVNP OCL precursors. This mostly reflects that NFATc1 can also enhance expression of this fusion molecule. ${ }^{(26)}$ Further, IL-6 enhances p38 mitogen-activated protein kinase (MAPK) signaling in MVNP OCL precursors (data not shown), which may also contribute to the hypermultinuclearity of OCLs formed in marrow cultures from MVNP mice. We previously reported that enhanced p38 MAPK signaling plays a critical role in the increased nuclear number per OCL in OCLs expressing the measles virus nucleocapsid gene. ${ }^{(9)}$

Marrow stromal cells from $p 62 \mathrm{KI} / \mathrm{T} / \mathrm{L}-6$ expressed higher levels of RANKL in response to $1,25-(\mathrm{OH})_{2} \mathrm{D}_{3}$ than the other mouse marrow stromal cells (Fig. $3 A$ ). The RANKL/OPG expression ratio in stromal cells from p62KI/TIL-6 was increased 3.5 -fold compared with WT (Fig. $3 A$ ). The stromal cells from $p 62 \mathrm{KI} / \mathrm{TIL}-6$ also expressed high levels of TAF12. The expression of TAF12 in stromal cells can result in hyperresponsivity to $1,25-(\mathrm{OH})_{2} \mathrm{D}_{3}$ and increased VDR transcription because at high levels, TAF12 acts as a coactivator of VDR transcription. ${ }^{(20)}$ Why $p 62 \mathrm{KI} / \mathrm{TIL}-6$ had higher expression of RANKL compared with p62KI stromal cells is not clear. Possibly, $p 62^{P 394 L}$ and IL-6 have additive effects on VDRTAF12 mediated transcription. These findings may in part explain the enhanced RANKL production present in the marrow microenvironment of pagetic patients.

p62KI/TIL-6 mice did not develop pagetic bone lesions or structural characteristics seen in pagetic patients. They only had increased $\mathrm{OCL}$ perimeter scores (Fig. 4A). In contrast, dynamic bone formation variables were similar to those in WT mice (Fig. 4, Table 1). These results suggest IL-6 is not enhancing osteoblast activity. Franchimont and colleagues ${ }^{(27)}$ report that IL-6 can modulate osteoblast proliferation, differentiation, and apoptosis, and supports osteoblast generation. However, as shown in Fig. 6, IL-6 only increased ALP expression in osteoblasts from MVNP mice. These results suggest high levels of IL- 6 are not sufficient to induce the enhanced bone formation characteristic of PD.

Interestingly, p62KI osteoblasts had increased expression of the Wnt signaling antagonist, Dkk1, which was further increased by IL-6 (Fig. 6A). Naot and colleagues ${ }^{(28)}$ reported increased expression of Dkk1 in osteoblast cultures from Paget's patients. The canonical Wnt pathway plays a key role in regulating osteoblast proliferation and differentiation. ${ }^{(29)}$ Tian and colleagues $^{(21)}$ have suggested that the release of Dkk1 from malignant plasma cells in multiple myeloma results in an inhibition of osteoblast proliferation, accentuating the imbalance between bone formation and bone resorption and facilitating local bone loss. In the $p 62 \mathrm{KI} / \mathrm{TIL}-6$ mice, overproduction of Dkk1 in osteoblasts could have a similar effect on bone formation. Possibly increased levels of IL-6 are responsible for the overexpression of Dkk1 in PD and contribute to the development of the lytic phase of PD through further accelerating local bone turnover. These results may explain in part why $p 62 \mathrm{KI} / \mathrm{T} / L-6$ mice did not develop pagetic lesions in vivo.

In summary, these results demonstrate that $p 62^{P 394 L}$ and $I L-6$ in combination increase $\mathrm{OCL}$ formation and activity, but are not sufficient to induce pagetic $\mathrm{OCL}$ and bone lesions characteristic of PD in vivo. Further, based on our findings that loss of IL- 6 in MVNP mice results in loss of their pagetic phenotype, these results demonstrate that IL- 6 is necessary but not sufficient to induce PD. These data further demonstrate that expression of high IL-6 in OCL confers many of characteristics of PD OCL (hyperresponsivity to $1,25-(\mathrm{OH})_{2} \mathrm{D}_{3}$, increased nuclei/OCL, increased bone resorption) but is not sufficient by itself or in combination with $p 62^{P 394 L}$ to induce PD. Thus, other factors induced by MVNP may also be required to enhance bone formation characteristics of PD, such as coupling factors or osteoblast stimulating factors. Recently, we found that MVNP but not $p 62^{P 394 L}$ increased expression of ephrinB2/EphB4, insulin-like growth factor 1 (IGF1), and semaphorin $3 \mathrm{~A}$, suggesting MVNP has multiple effects beyond upregulating IL- 6 to induce PD (ASBMR 2013 Abstract). ${ }^{(30)}$

\section{Disclosures}

GDR is a consultant to Amgen. All other authors state that they no conflicts of interest.

\section{Acknowledgments}

This work was supported by R01-AR057308 (to GDR) and R01AR057310 (to DLG) from NIH-NIAMS, 5P30CA016059 (to JJW) from $\mathrm{NIH} / \mathrm{NCl}$ Cancer Center support grant, and W81XWH-12-10533 (to NK) from Department of Defense. This research project was provided the VCU transgenic/knockout Mouse Shared Resource.

Authors' roles: GDR and NK designed study and wrote the paper; JT, YK, and NK performed the experiments; MAS and JJW generated the transgenic mice; and $\mathrm{HZ}$ and DWD performed historical section and analysis. JJW, DWD, DLG, GDR, and NK did the data interpretation. All authors approved the submission of manuscript.

\section{References}

1. Hosking DJ. Paget's disease of bone. Br Med J (Clin Res Ed) 1981;283:686-8.

2. Kanis JA, Simon LS. Metabolic consequences of bone turnover in Paget's disease of bone. Clin Orthop. 1987;217:26-36.

3. Siris ES, Roodman GD. Paget's Disease of Bone, Primer on the Metabolic Bone Diseases and Disorders of Mineral Metabolism, Chapter 80. American Society for Bone and Mineral; 2013. p. 659-669.

4. Roodman GD, Kurihara N, Ohsaki Y, et al. Interleukin 6. A potential autocrine/paracrine factor in Paget's disease of bone. J Clin Invest. 1992;89:46-52.

5. Hoyland JA, Freemont AJ, Sharpe PT. Interleukin-6, IL-6 receptor, and IL-6 nuclear factor gene expression in Paget's disease. J Bone Miner Res. 1994;1:75-80.

6. Roodman GD, Windle JJ. Paget disease of bone. J Clin Invest 2005:115:200-8.

7. Kurihara N, Reddy SV, Menaa C, et al. Osteoclasts expressing the measles virus nucleocapsid gene display a pagetic phenotype. J Clin Invest. 2000;105:607-14. 
8. Kurihara N, Zhou H, Reddy SV, et al. Expression of measles virus nucleocapsid protein in osteoclasts induces Paget's disease-like bone lesions in mice. J Bone Miner Res. 2006;21:446-55.

9. Kurihara N, Hiruma Y, Yamana K, et al. Contributions of the measles virus nucleocapsid gene and the SQSTM1/p62(P392L) mutation to Paget's disease. Cell Metab. 2011;13:23-34.

10. Sundaram K, Shanmugarajan S, Rao DS, et al. Mutant p62 $2^{\mathrm{P} 392 \mathrm{~L}}$ stimulation of osteoclast differentiation in Paget's disease of bone. Endocrinology. 2011;152:4180-9.

11. Hiruma $Y$, Kurihara N, Subler MA, et al. A SQSTM1/p62 mutation linked to Paget's disease increases the osteoclastogenic potential of the bone microenvironment. Hum Mol Genet. 2008;17:3708-19.

12. Kurihara N, Hiruma $\mathrm{Y}, \mathrm{Zhou} \mathrm{H}$, et al. Mutation of the sequestosome 1 (p62) gene increases osteoclastogenesis but does not induce Paget disease. J Clin Invest. 2007;117:133-42.

13. Reddy SV, Scarcez T, Windle JJ, et al. Cloning and characterization of the $5^{\prime}$-flanking region of the mouse tartrate-resistant acid phosphatase gene. J Bone Miner Res. 1993;8:1263-70.

14. Reddy SV, Hundley JE, Windle JJ, et al. Characterization of the mouse tartrate resistant acid phosphatase (TRAP) gene promoter. J Bone Miner Res. 1995;4:601-6.

15. Nagy A, Gertsenstein M, Vintersten K, et al. Manipulating the mouse embryo. A laboratory manual. 3rd ed. Cold Spring Harbor, NY: CSHL Press; 2003.

16. Ishizuka H, García-Palacios V, Lu G, et al. ADAM8 enhances osteoclast precursor fusion and osteoclast formation in vitro and in vivo. J Bone Miner Res. 2011;26:169-81.

17. Parfitt AM, Drezner MK, Glorieux FH, et al. Bone histomorphometry: standardization ofnomenclature, symbols, and units. Report of the ASBMR Histomorphometry Nomenclature Committee. J Bone Miner Res. 1987;2:595-610.

18. Sudo $H$, Kodama $H A$, Amagai $Y$, et al. In vitro differentiation and calcification in a new clonal osteogenic cell line derived from newborn mouse calvaria. J Cell Biol. 1983;96:191-8.

19. Meloan SN, Puchtler H. Chemical mechanisms of staining methods: von Kossa's technique. What von Kossa really wrote and a modified reaction for selective demonstration of inorganic phosphate. J Histotechol. 1985;8:11-3.

20. Kurihara N, Reddy SV, Araki N, et al. Role of TAFII-17, a VDR binding protein, in the increased osteoclast formation in Paget's disease. J Bone Miner Res. 2004;19:1154-64.

21. Tian E, Zhan F, Walker $\mathrm{R}$, et al. The role of the Wnt-signaling antagonist DKK1 in the development of osteolytic lesions in multiple myeloma. N Engl J Med. 2003;349:2483-94.

22. Daroszewska A, van't Hof RJ, Rojas JA, et al., A point mutation in the ubiquitin-associated domain of SQSMT1 is sufficient to cause a Paget's disease-like disorder in mice. Hum Mol Genet. 2011;20:2734-44.

23. Yagi M, Miyamoto T, Sawatani $Y$, Iwamoto $K$, et al. DC-STAMP is essential for cell-cell fusion in osteoclasts and foreign body giant cells. J Exp Med. 2005;202:345-51.

24. Yagi M, Miyamoto T, Toyama Y, Suda T. Role of DC-STAMP in cellular fusion of osteoclasts and macrophage giant cells. J Bone Miner Metab. 2006;24:355-8.

25. Lee MS, Kim HS, Yeon JT, et al. GM-CSF regulates fusion of mononuclear osteoclasts into bone-resorbing osteoclasts by activating the Ras/ERK pathway. J Immunol. 2009;183:3390-9.

26. Kim K, Lee SH, Ha Kim J, et al. NFATc1 induces osteoclast fusion via up-regulation of Atp6v0d2 and the dendritic cell-specific transmembrane protein (DC-STAMP). Mol Endocrinol. 2008;22:176-8.

27. Franchimont $\mathrm{N}$, Wertz $\mathrm{S}$, Malaise $\mathrm{M}$. Interleukin-6: an osteotropic factor influencing bone formation? Bone. 2005;37:601-6.

28. Naot D, Bava U, Matthews B, et al. Differential gene expression in cultured osteoblasts and bone marrow stromal cells from patients with Paget's disease of bone. J Bone Miner Res. 2007;22:298-309.

29. Gong Y, Slee RB, Fukai N, et al. Osteoporosis-Pseudoglioma Syndrome Collaborative Group. LDL receptor-related protein 5 (LRP5) affects bone accrual and eye development. Cell. 2001;107: 513-23.

30. Kurihara N, Teramachi J, Kitagawa Y, et al. IFGI contributes to the increased bone formation by measles virus nucleocapsid protein expressed by osteoclasts in Paget's Bone Disease. J Bone Miner Res. 2013, 28 sup 1 (Abstract \#FR440). 


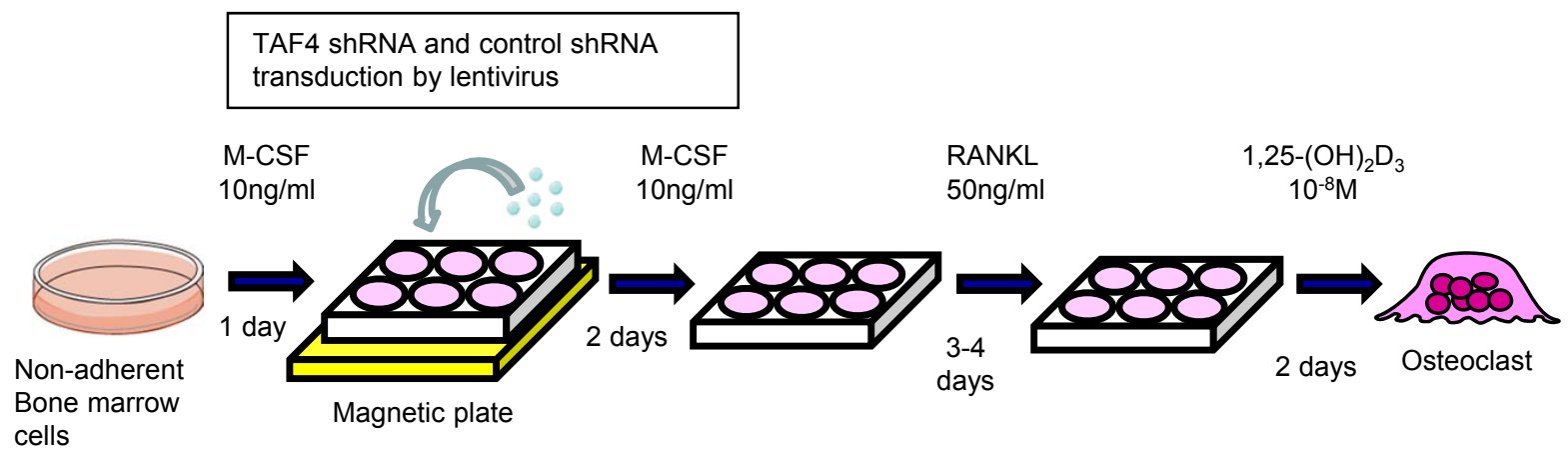

Figure 1. Culture procedure for the effects of TAF4 knocked down on mouse OCL formation. Non-adherent bone marrow cells from WT and TRAP-MVNP were transduced with TAF4 shRNA or control shRNA using lentivirus and the Viromag System ${ }^{\mathrm{TM}}$.

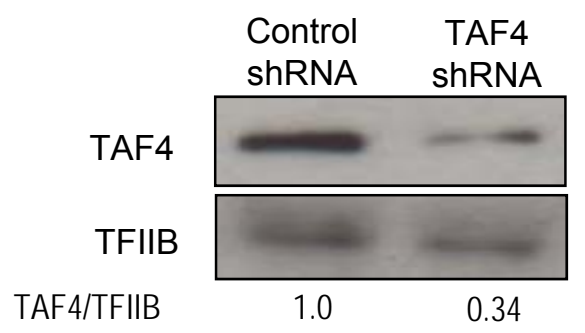

Figure 2. TAF4 Expression in TAF4 shRNA or Control shRNA transduced MVNP OCL. Cell lysates from OCL were subjected to Western blotting to examine the effects of TAF4 knockdown. TAF4 expression was analyzed using a specific monoclonal antiTAF4 antibody (Santa Cruz). TFIIB was assayed by Western blotting as a loading control. 


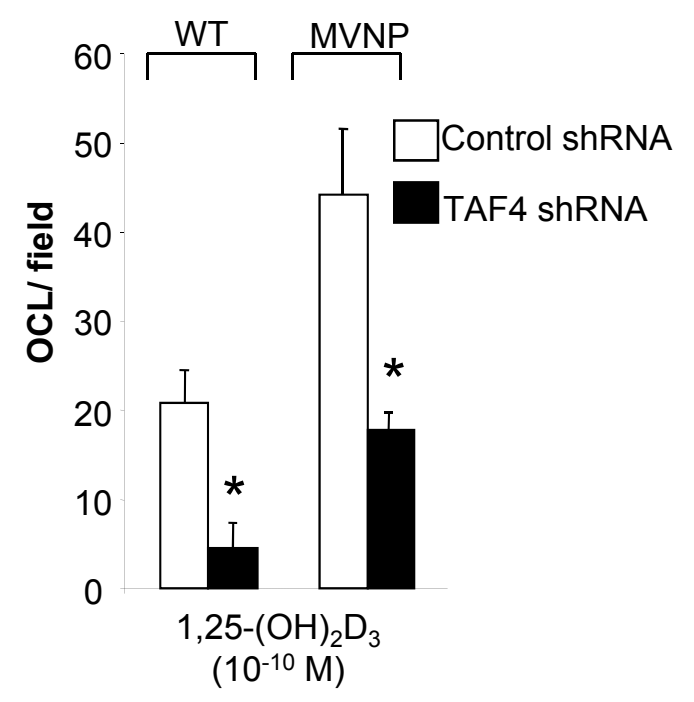

Figure 3. Osteoclast formation by TAF4 shRNA or non-mammalian control shRNA transduced WT or MVNP OCL-precursors. MNC number per field. The OCL were counted in 20 random fields. The data shows the mean $\pm S D(n=4)$. * $p<0.01$ compared to control shRNA transduced cultures.

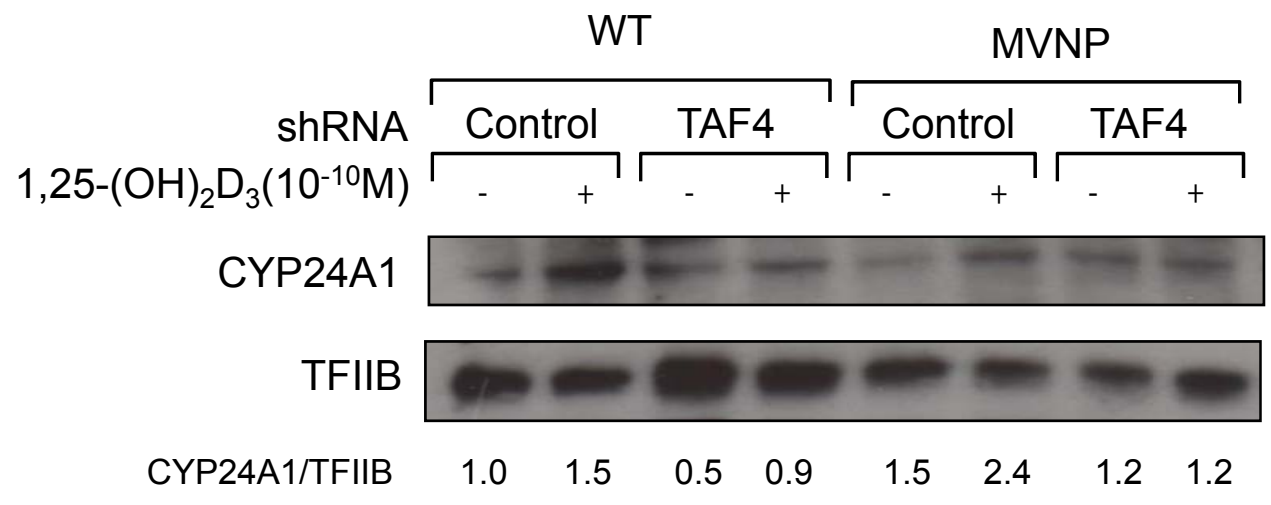

Figure 4. TAF4 knockdown OCLs decreased induction of CYP24A1. Osteoclasts were derived from TAF4 shRNA or control shRNA transduced WT or MVNP OCL precursors as shown Figure 1. The cultures were treated with vehicle or $10^{-10} \mathrm{M} 1,25-$ $(\mathrm{OH})_{2} \mathrm{D}_{3}$. Then the cells were collected and the expression of CYP24A1 and TFIID were assayed by Western blotting using appropriate monoclonal antibodies. 

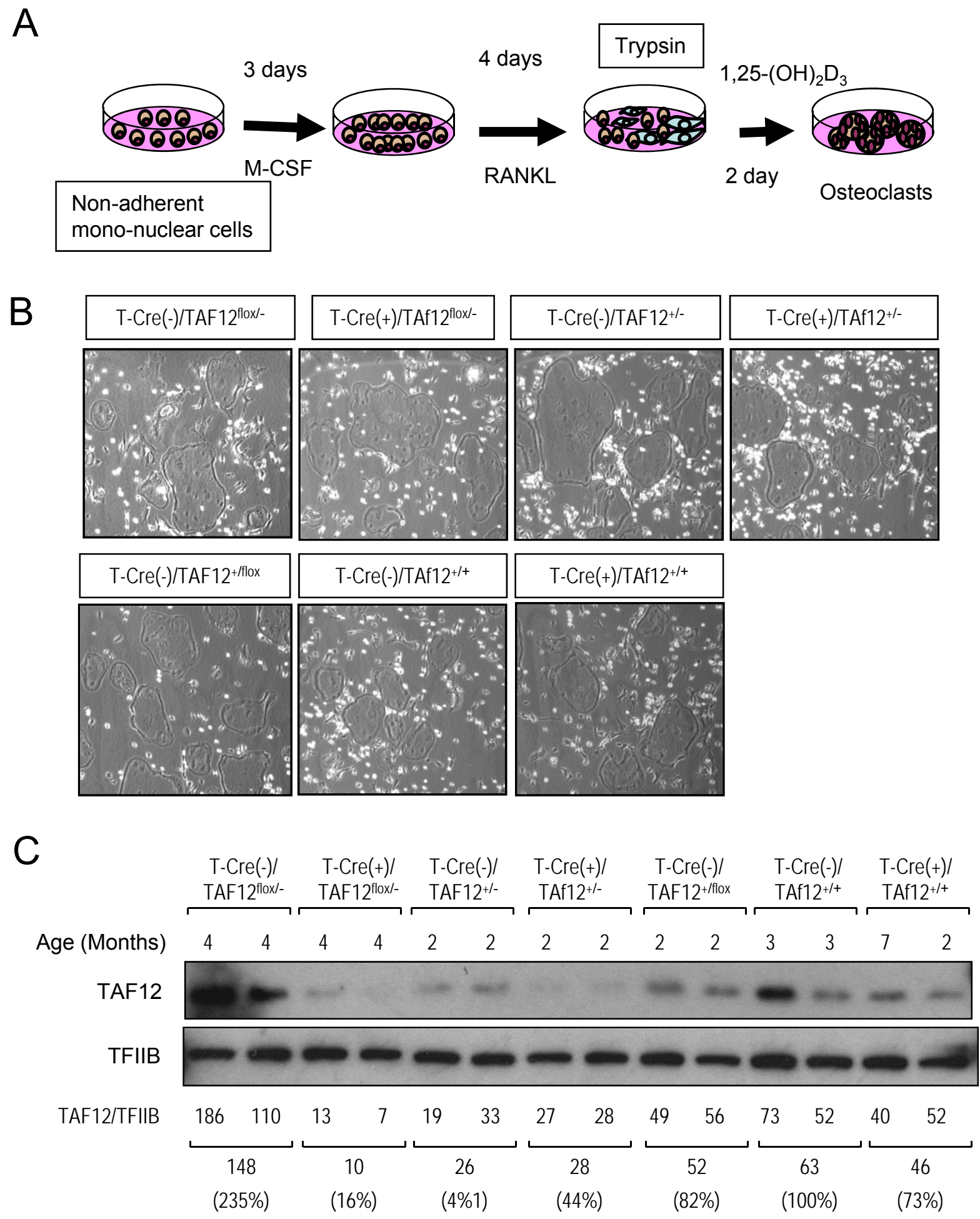

Figure 5. Characterization of TAF12 Knockdown mice. A. The culture procedure for preparing enriched osteoclasts from whole bone marrow cultures. B. In situ view. Bone marrow mononuclear cells from a variety of conditional knockout mice were cultured according to protocol as shown Figure 5A. C. TAF12 expression levels expressed a variety of TRAP-Cre x TAF12 floxed mice. Non-adherent bone marrow cells from these mice were cultured as shown Figure $5 \mathrm{~A}$, the cell-lysates were collected in RIPA buffer after culture. TAF12 expression was evaluated by Western blotting using TAF12 polyclonal antibody (Protein Tech, Chicago IL.). TAF12 expression levels were measured by using Image-J softwear. 
A Cre(-)/ Cre(+)/

WT TAF12flox- TAF12 flox

TAF12

$\begin{array}{llll}\text { TAF12/TFIB } & 1.0 & 1.2 & 0.5\end{array}$

VDR

$\begin{array}{llll}\text { VDR/TFIIB } & 1.0 & 1.0 & 0.5\end{array}$

TFIIB

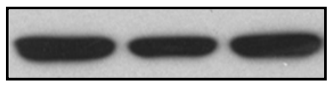

B

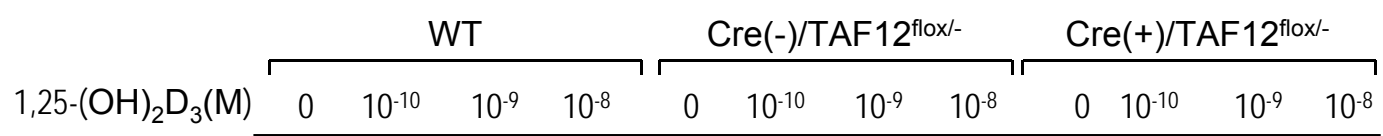

CYP24A1

TFIIB

C
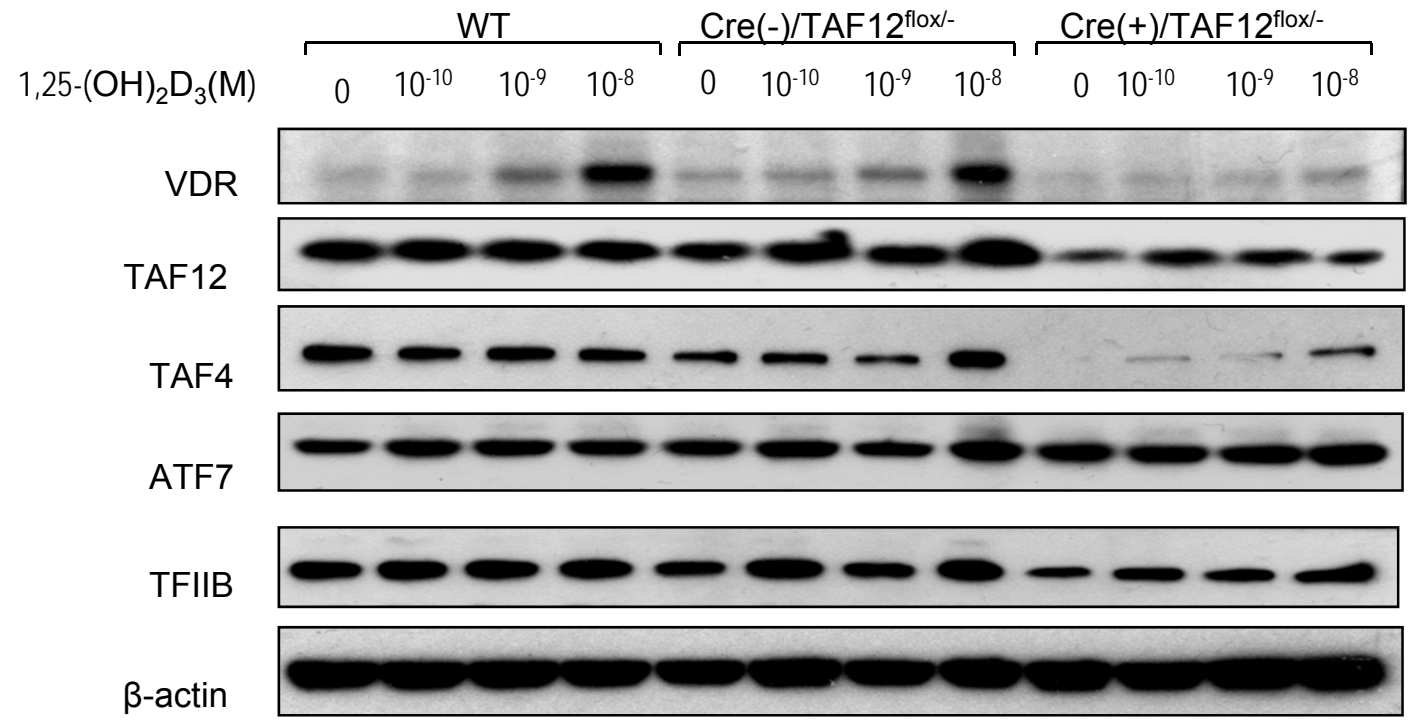

Figure 6. Analysis of osteoclasts from TRAP-Cre(+)/TAF12 ${ }^{\text {floxl-, }}$, TRAP-Cre(-)/TAF12 $12^{\text {flox/- }}$ or WT mice. A. The expression of TAF12 and VDR. Non-adherent mononuclear cells from TRAP-Cre()/TAF12flox/-, TRAP-Cre(+)/TAF12 flox/- or WT mice were cultured as shown in Figure 5A. The cell lysates were collected and analyzed for TAF12 and VDR expression by Western blotting using TAF12 or VDR antibody. The levels of TAF12 or VDR were evaluated by image $\mathrm{J}$ software. B. Expression of CYP24A1 induced by 1,25-(OH) $2_{2} \mathrm{D}_{3}$. Osteoclasts formed from TRAP-Cre(-)/TAF12 flox/-, TRAP$\mathrm{Cre}(+) / \mathrm{TAF} 12^{\text {floxl- }}$ or WT mice OCL precursors were scraped with a rubber policeman, then OCLs ( $2 \times 10^{5} /$ well ) were re-plated in 12 well-plates and cultured with $10 \%$ FCS in aMEM and $1,25-(\mathrm{OH})_{2} \mathrm{D}_{3}$ for 24 hours. The cells were collected and the expression of CYP24A1 was assayed by Western blotting using mouse anti-CYP24A1 monoclonal antibody (Abcam). C. Expression TAF12 binding molecules. OCL precursors were scraped with a rubber policeman, then OCLs ( 2 X105/well ) were replated in 12 well-plates and cultured with $10 \%$ FCS in aMEM and 1,25-(OH $)_{2} \mathrm{D}_{3}$ for 48 hours. These cells were collected and the expression of TAF12 binding molecules were assayed by Western blotting using appropriate monoclonal antibody. 

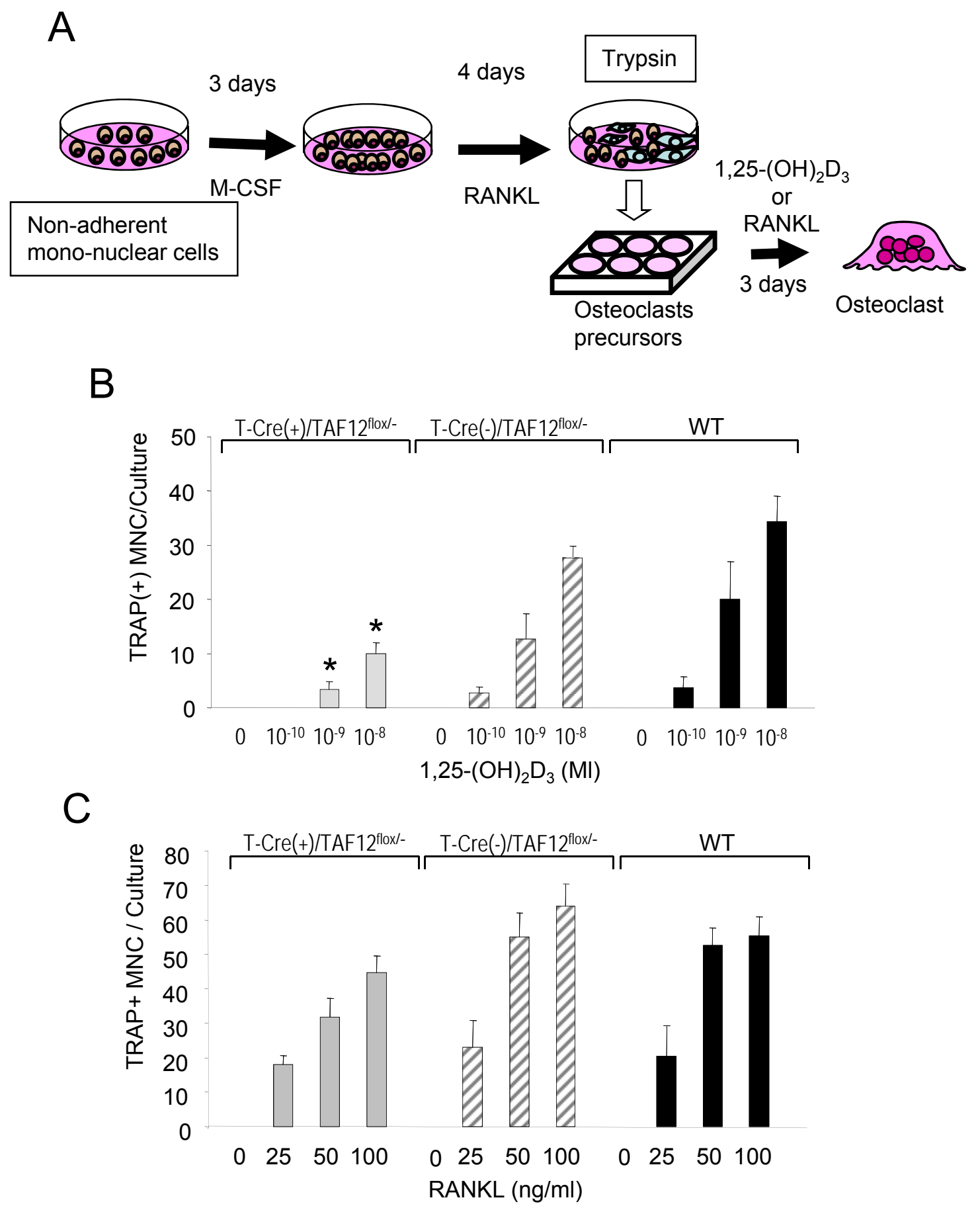

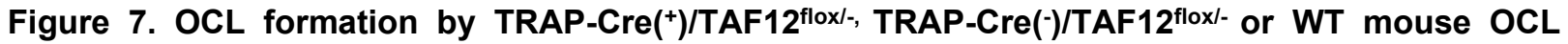
precursors. A. The culture protocol for osteoclast formation. B. Non-adherent mouse marrow mononuclear cells $\left(1 \times 10^{4}\right)$ were cultured as shown Figure7A in the presence or absence of 1,25 $(\mathrm{OH})_{2} \mathrm{D}_{3}$ in aMEM with $10 \% \mathrm{FCS}$ for 72 hours. At the end of the cultures, cells were fixed and OCLs were stained for TRAP. Cells with $>3$ nuclei/cell and TRAP positivity were counted as OCL. Data are shown as the mean $\pm S D(n=4)$. ${ }^{*} ; p<0.01$ compared to WT cultures. C. Non-adherent mouse marrow mononuclear cells $\left(1 \times 10^{4}\right)$ were cultured as shown Figure7A in the presence of RANKL in aMEM with $10 \% \mathrm{FCS}$ for 72 hours. At the end of the cultures, cells were fixed and OCLs were stained for TRAP. Cells with $>3$ nuclei/cell and TRAP positivity were counted as OCL. Data are shown as the mean \pm SD $(n=4)$. 